\title{
Pressure-Driven Opening and Filling of a Volcanic Hydrofracture Recorded by Tuffisite at Húsafell, Iceland: A Potential Seismic Source
}

\author{
Holly E. Unwin ${ }^{1 *}$, Hugh Tuffen ${ }^{1}$, Emrys Phillips ${ }^{2}$, Fabian B. Wadsworth ${ }^{3}$ and \\ Mike R. James ${ }^{1}$ \\ 'Lancaster Environment Centre, Lancaster University, Lancaster, United Kingdom, ${ }^{2}$ British Geological Survey, The Lyell \\ Centre, Edinburgh, United Kingdom, ${ }^{3}$ Department of Earth Sciences, Durham University, Durham, United Kingdom
}

OPEN ACCESS

Edited by:

Derek Keir,

University of Southampton, United Kingdom

Reviewed by:

Simon Thivet,

UMR 6524 Laboratoire Magmas et Volcans (LMV), France Madison Myers,

Montana State University, United States

*Correspondence: Holly E. Unwin

h.unwin@lancaster.ac.uk

Specialty section: This article was submitted to Volcanology, a section of the journal Frontiers in Earth Science

Received: 15 February 2021 Accepted: 22 April 2021 Published: 03 June 2021

Citation:

Unwin HE, Tuffen H, Phillips E, Wadsworth FB and James MR (2021)

Pressure-Driven Opening and Filling of a Volcanic Hydrofracture Recorded by Tuffisite at Húsafell, Iceland: A Potential Seismic Source.

Front. Earth Sci. 9:668058. doi: 10.3389/feart.2021.668058
The opening of magmatic hydraulic fractures is an integral part of magma ascent, the triggering of volcano seismicity, and defusing the explosivity of ongoing eruptions via outgassing magmatic volatiles. If filled with pyroclastic particles, these fractures can be recorded as tuffisites. Tuffisites are therefore thought to play a key role in both initiating eruptions and controlling their dynamics, and yet their genesis remains poorly understood. Here we characterise the processes, pressures and timescales involved in tuffisite evolution within the country rock through analysis of the sedimentary facies and structures of a large sub-horizontal tuffisite vein, $0.9 \mathrm{~m}$ thick and minimum $40 \mathrm{~m}$ in length, at the dissected Húsafell volcano, western Iceland. The vein occurs where a propagating rhyolitic sheet intrusion stalled at a depth of $\sim 500 \mathrm{~m}$ beneath a relatively strong layer of welded ignimbrite. Laminations, cross-stratification, channels, and internal injections indicate erosion and deposition in multiple fluid pulses, controlled by fluctuations in local fluid pressure and changes in fluid-particle concentration. The field evidence suggests that this tuffisite was emplaced by as many as twenty pulses, depositing sedimentary units with varying characteristics. Assuming that each sedimentary unit ( $0.1 \mathrm{~m}$ thick and minimum $40 \mathrm{~m}$ in length) is emplaced by a single fluid pulse, we estimate fluid overpressures of $~ 1.9-3.3 \mathrm{MPa}$ would be required to emplace each unit. The Húsafell tuffisite records the repeated injection of an ash-laden fluid within an extensive subhorizontal fracture, and may therefore represent the fossil record of a low-frequency seismic swarm associated with fracture propagation and reactivation. The particles within the tuffisite cool and compact through time, causing the rheology of the tuffisite fill to evolve and influencing the nature of the structures being formed as new material is injected during subsequent fluid pulses. As this new material is emplaced, the deformation style of the surrounding tuffisite is strongly dependent on its evolving rheology, which will also control the evolution of pressure and the system permeability. Interpreting tuffisites as the fossil record of fluid-driven hydrofracture opening and evolution can place new constraints on the cycles of pressurisation and outgassing that accompany the opening of magmatic pathways, key to improving interpretations of volcanic unrest and hazard forecasting.

Keywords: volcanic earthquakes, volcanic degassing, conduit, hydrofracture, rhyolite, magma fragmentation, tuffisite 


\section{INTRODUCTION}

Magma ascent typically requires the upward propagation of fractures in the shallow crust, producing pathways to transport magma and exsolved gases. Fracture formation is controlled by fluid pressure, the surrounding stress field, and country rock properties (Rubin, 1995; Gudmundsson, 2011; Geshi et al., 2012). Whereas mafic dyke emplacement models account for the associated fracturing of country rock (e.g., Taisne and Jaupart, 2009; Rivalta et al., 2015), this aspect has received surprisingly little attention for silicic magma. As fragmentation is expected to be characteristic of the ascent of silicic magma within the upper two kilometres of the crust (Wadsworth et al., 2020), the first silicic magma entering a propagating fracture tip will be in a fragmental state (e.g., Heiken et al., 1988). The opening of silicic magma pathways will therefore differ from their mafic equivalents, with a gas-pyroclast mixture at the propagating fracture tip, rather than intact magma following an initial gas pocket (Rubin, 1995). Field evidence suggests that fractures in silicic systems may also open laterally as off-shoots from a main sub-vertical fracture network or conduit (Stasiuk et al., 1996). A tuffisite is formed where the fragmented material is transported and deposited within the opening fracture system. The scarcity of well-exposed fossil silicic conduit systems has hindered advances in understanding, and a principal motivation for this study is to provide the most detailed description of a tuffisite within such a silicic system.

Documented shallow silicic conduit systems, whether exposed by erosion (Stasiuk et al., 1996; Tuffen and Dingwell, 2005), intercepted by boreholes (Eichelberger et al., 1986; Heiken et al., 1988) or reconstructed from ejected pyroclasts (Castro et al., 2014; Isgett et al., 2017; Colombier et al., 2020), have a number of key characteristics. The main conduit is plugged by coherent magma, which may contain healed clastic textures that indicate cycles of fracture, ephemeral clastic transport, and healing (internal tuffisite veins in Figure 1; Tuffen and Dingwell, 2005). Where the conduit walls are exposed, tuffisite veins are observed propagating into the country rock (external tuffisite veins in Figure 1; Stasiuk et al., 1996; Heiken et al., 1988). Diverse clast types in internal and external tuffisites indicate fractureenabled material transport over distances of hundreds of metres within the shallow conduit systems (Saubin et al., 2016).

Tuffisites have been invoked as outgassing pathways (Jaupart, 1998; Castro et al., 2012, 2014; Berlo et al., 2013; Farquharson et al., 2017; Heap et al., 2019; Kolzenburg et al., 2019), providing focussed loci for gas escape, in contrast with more widely distributed gas leakage through permeable country rocks (e.g., Eichelberger et al., 1986; Rust et al., 2004; Lavallée et al., 2013; Farquharson et al., 2015). In particular, external tuffisites have been touted as pathways for significant escape of magmatic gases from the main conduit zone, perhaps dissipating sufficient gas pressure to trigger a change in eruption style from explosive toward dominantly effusive (Stasiuk et al., 1996; Castro et al., 2014). However, the details of how this transition takes place remain contested, and existing models of tuffisite-enabled outgassing, which hinge upon the temporal evolution of permeability, are necessarily simplistic.
The permeability of tuffisites is transient as deposition will clog the fracture (e.g., Tuffen et al., 2003; Saubin et al., 2016; Heap et al., 2019), and sintering of deposited particles will further decrease permeability, slowing outgassing (Stasiuk et al., 1996; Okumura and Sasaki, 2014; Wadsworth et al., 2016; Gardner et al., 2018). Current models of the permeability evolution of external tuffisites assume instantaneous filling of the entire tuffisite by a single pulse of particles (Kolzenburg et al., 2019; Wadsworth et al., 2021).

Improved understanding of outgassing through external tuffisites needs to build upon geological evidence from dissected systems, which preserve details of tuffisite deposition. Unsteady flow in the volcanic conduit produces pressure fluctuations that control the formation and input of material into the evolving tuffisite. A basic but enigmatic question is whether tuffisites are "single-pulse," carrying only one pulse of particle-laden gas, or whether they are repeatedly reactivated - as inferred in source models for low-frequency volcanic earthquakes that involve the repetitive, non-destructive resonance of a stationary fluid-filled crack (Figure 1; Chouet, 1996; Kumagai and Chouet, 2000). Low-frequency seismic events can cluster into swarms whose shifting waveforms indicate a systematic change in the nature of crack resonance, interpreted as particles progressively filling a fracture system (Molina et al., 2004). Seismic trigger models appealing to crack resonance (e.g., Chouet, 1996) require the injection of pressurised fluid into a fracture tens or hundreds of metres in length. Although this is consistent with the geochemically-inferred extent of tuffisite veins in the Chaitén conduit (Castro et al., 2014; Saubin et al., 2016), there is little detailed documentation of such extensive tuffisite systems in the geological record. Tighter constraints on the longevity of fluid flow through tuffisite veins will assist modelling of both pre-eruptive unrest and eruption dynamics, thus improving forecasting of volcanic hazards.

In this paper we begin to address this knowledge gap by interpreting the structures in the fill of a large $(0.9 \mathrm{~m}$ wide, 40 m long) tuffisite emanating from a silicic conduit at Húsafell volcano in west Iceland (Saubin et al., 2019), interpreted as recording fluctuations in fluid pressure and variations in the fluid characteristics during tuffisite formation. By identifying individual depositional units and the relationships between them, we have been able to constrain the fluid pressure required for tuffisite formation, as well as the timescales involved.

\section{CHARACTERISTICS AND FORMATION OF TUFFISITES}

Tuffisites are particle-filled fractures found within volcanic conduits or the surrounding country rock (Figure 1; Heiken et al., 1988; Tuffen et al., 2003). Internal tuffisites form within volcanic conduits and propagate through hot magma when stresses rise to meet or exceed the strength of the magma (equivalently, the rates of deformation imparted by those rising stresses exceed the inverse relaxation time of the magma and cause mode 2 or 3 fractures; Tuffen and Dingwell, 2005). Such internal tuffisites form interconnected networks of fractures (Kendrick et al., 


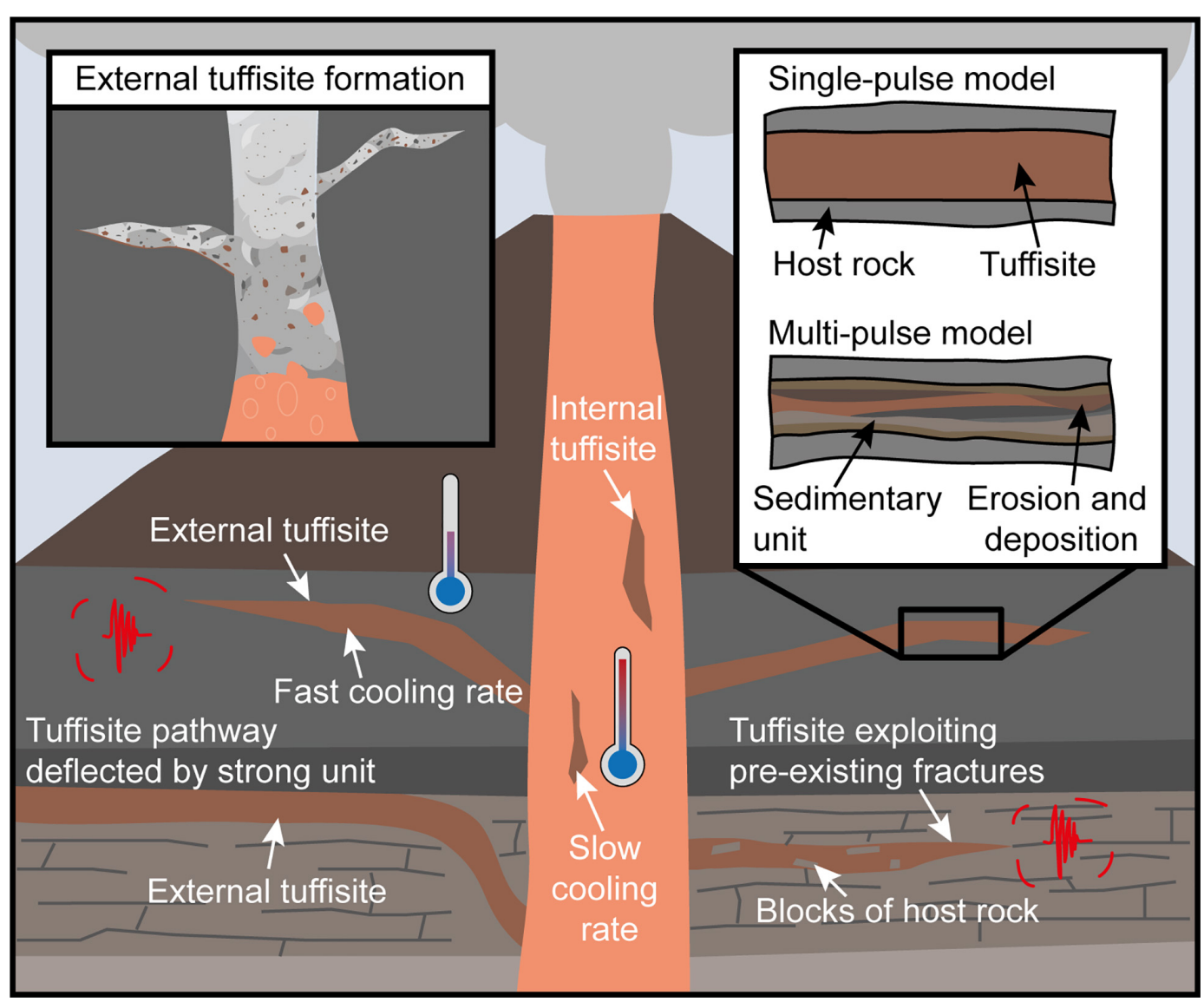

FIGURE 1 | Schematic showing the position of internal and external tuffisites with relation to the volcanic conduit. Internal tuffisites form within volcanic conduits, propagating through hot magma itself. External tuffisites form in the country rock surrounding the conduit when the fluid pressure exceeds the strength of the country rock. The morphology of external tuffisites, like magmatic dykes and sills, is influenced by the characteristics of the host rock. Tuffisites can be guided by pre-existing fractures, exploiting the easiest pathway for propagation. Strong units may act as barriers to fracture propagation, deflecting or temporarily stalling a propagating fracture. External tuffisites will cool more rapidly than internal tuffisites, as they are injected into the cold country rock. Tuffisites formed by only one pulse of material will have a simple internal structure, typically with fine-grained margins grading into a coarser-grained centre. Tuffisites formed by multiple pulses have a more complex structure, with multiple sedimentary units that may have erosive boundaries.

2016; McGowan, 2016; Saubin et al., 2016; Paisley et al., 2019a). By contrast, external tuffisites form in country rock when the fluid pressure exceeds the country rock strength, and must also overcome the lithostatic stress exerted by the overlying rock to widen (mode 1 fractures; Hubbert and Willis, 1957). This mechanism is comparable to the formation of magmatic dykes and sills (Rubin, 1995), glacial hydrofractures (Rijsdijk et al., 1999; Van Der Meer et al., 1999; Phillips et al., 2013; Phillips and Hughes, 2014) and sand injectites (Cosgrove, 2001; Boehm and Moore, 2002; Cobain et al., 2015). The similarities of external tuffisites to hydrofractures in sedimentary settings lead us to interpret tuffisites as a sub-set of hydrofractures, though the different temperature, pressure and fluid characteristics of tuffisites (Heiken et al., 1988; Castro et al., 2012) to the wateropened hydrofractures of other environments (Jonk, 2010) must be acknowledged.

External tuffisites are particle-filled sub-vertical or subhorizontal fractures that are connected to the conduit, often following weaknesses such as pre-existing fractures (Figure 1;
Stasiuk et al., 1996). These tuffisites range from millimetres to over a metre in width and from tens of centimetres to tens of metres in length, and branch to form smaller fractures toward the tip of the main vein (Heiken et al., 1988; Stasiuk et al., 1996). Tuffisites are filled with lithic and juvenile clasts, including pumice and dense lava fragments, with clasts ranging from microns to centimetres in size (McGowan, 2016; Saubin et al., 2016).

In both internal and external tuffisites, clasts may be organised into different layers or units, resembling bedding (Heiken et al., 1988; Tuffen et al., 2003; Tuffen and Dingwell, 2005), or the tuffisite interior may lack obvious internal structure (Saubin et al., 2016). The presence of bedded units and structures such as crossstratification and graded bedding suggest substantial fluid flow through the fracture (Heiken et al., 1988; Tuffen et al., 2003; van der Meer et al., 2009; Hurst et al., 2011; Phillips et al., 2013).

At the sub-surface depth of tuffisite formation $(<2 \mathrm{~km})$ the silicic magma column is likely to be fragmented (Wadsworth et al., 2020), providing a ready source of clastic material to be 
injected into hydrofractures within the country rock. Explosive volcanic eruptions and the associated volcanic ash plumes are unsteady, with pressure fluctuations that can drive fracture and tuffisite formation. Once a sufficient critical fluid pressure is reached, a hydrofracture can be opened. Hydrofracture opening produces a drop in fluid pressure in the gas-ash dispersion, creating a pressure gradient that facilitates the transport and injection of gas and particles into the evolving fracture system (Heiken et al., 1988; Jolly and Lonergan, 2002). Spatial or temporal variations in fluid velocity inside the fracture can lead to changes in fracture thickness, particle settling or erosion of the deposited particles, potentially developing sedimentary structures such as cross-bedding (Kern et al., 1959; Heiken et al., 1988; Phillips et al., 2013). Large particles can initially prop open the fracture as it closes, maintaining its permeability, but through time the fracture may become clogged with finer particles (Farquharson et al., 2017; Heap et al., 2019). In many tuffisites, there is evidence that the particles compact and sinter together at the end of the tuffisite lifecycle, further reducing permeability and limiting the period of degassing (Tuffen et al., 2003; Heap et al., 2019). The ability of a tuffisite to sinter is related to its temperature, and the melt proportion, such that only melt-rich tuffisites that can remain sufficiently insulated from cooling can sinter and weld shut (Wadsworth et al., 2014, 2021; Kolzenburg et al., 2019).

The lifetime of a tuffisite has been inferred using the timescales of welding and compaction, together with dissolved water and trace element diffusion gradients around veins. Inferred timescales for gas transport within veins range from $\sim 15 \mathrm{~min}$ to $\sim 1$ day (Castro et al., 2012; Berlo et al., 2013; Saubin et al., 2016; Paisley et al., 2019b; Wadsworth et al., 2019). $\mathrm{H}_{2} \mathrm{O}$ concentrations in glass-walled tuffisites allow for estimates of the pressure changes associated with tuffisite formation, including transient pressure drops on fracture opening of a few megapascals, and also, in some instances, the ephemeral development of overpressure inside the tuffisite due to blockages (Castro et al., 2014).

\section{LOCATION AND GEOLOGICAL SETTING OF THE HÚSAFELL STUDY AREA}

Húsafell volcano, in west Iceland ( $80 \mathrm{~km} \mathrm{NE}$ of Reykjavik), was active at 3-2.5 Ma, with three phases of silicic volcanism separated by glacial events and mafic eruptions (Sæmundsson and Noll, 1974; Figure 2). The first phase of activity began with the emplacement of dacitic lavas $>100 \mathrm{~m}$ thick, exposed to the west of Húsafell (Figure 2), followed by the deposition of the Hraunfossar ignimbrite. The second phase of activity was more explosive, consisting of rhyolitic ash-dominated fall deposits and ignimbrites, including the Deildargil ignimbrite, well-exposed in the valley of Deildargil, the location of this study (Sæmundsson and Noll, 1974). In the third phase of activity numerous dacitic and rhyolitic lavas, rhyolitic ash-dominated fall deposits and ignimbrites were emplaced before the volcano was buried by a thick succession of basalt lava flows originating east of Húsafell. Large volumes of ignimbrite were emplaced and, during the final phase, numerous SW-NE dipping silicic dykes, sheets, domes, and vents were formed (Sæmundsson and Noll, 1974). These features have been dissected in the valley of Deildargil $(140 \mathrm{~m}$ above sea level), where there is a silicic intrusion emplaced at $\sim 500 \mathrm{~m}$ depth, as inferred from magmatic $\mathrm{OH}^{-}$in hydrous glasses (McGowan, 2016). This intrusion outcrops as multiple segments along the valley, cross-cutting a series of ignimbrites, conglomerates, and basaltic lavas (Saubin et al., 2019). The ignimbrite appears to have deflected the ascending rhyolitic sheet, temporarily stalling its ascent (McGowan, 2016). A nearhorizontal tuffisite $\sim 0.9 \mathrm{~m}$ wide and $40 \mathrm{~m}$ long cuts through the contact separating a lower densely welded ignimbrite from an overlying more friable, less densely welded ignimbrite (Figure 3). Lack of exposure at both ends of the tuffisite outcrop prevents the preservation of the true length of the tuffisite and the fracture tip, but provides a detailed view of the structures within the tuffisite fill. Due to the spatial proximity, and similarities in their juvenile and country rock componentry and clastic textures within their tuffisitic margins (McGowan, 2016; Saubin et al., 2019), we infer that the tuffisite and rhyolitic sheet intrusion record the same magmatic event, despite the lack of a continuously exposed outcrop connecting the two.

\section{FIELD METHODS}

The Húsafell tuffisite provides an opportunity to analyse the facies and structures of a tuffisite in detail. The field evidence is key for the reconstruction of tuffisite evolution and interpretation as a record of fluid pressure through time. Vertical graphic logs were taken every $\sim 2 \mathrm{~m}$ along the main body of the tuffisite, recording the characteristics of each unit including particle size and details of any structures present within the unit. Different units were identified by changes in particle-size, clast abundances or composition. The composition of the clasts and matrix material was established in the field with aid of a hand lens. The northern end of the tuffisite forms part of a vertical cliff outcrop, with sections that could not be accessed for logging in the field. Graphic logs were instead produced from high resolution panorama-style photographs of the outcrop, groundtruthed using observations of the same units accessible laterally, where possible. These photographs were also used to connect logs to create a structural interpretation of the whole outcrop. Oriented samples collected across the length of the outcrop were thin sectioned, enabling the examination of the range of microstructures present within the different units identified within the tuffisite.

\section{FIELD OBSERVATIONS}

\section{The Tuffisite Morphology and Broad Structure}

The tuffisite occurs horizontally along the contact between two ignimbrite units, forming a sill of pyroclastic material (Figure 3). The tuffisite fill is composed of a mixture of rhyolitic pumice, dense obsidian and ash shards, together with fragments of the surrounding ignimbrite. The unit beneath the tuffisite and forming its lower boundary is a welded ignimbrite unit composed 


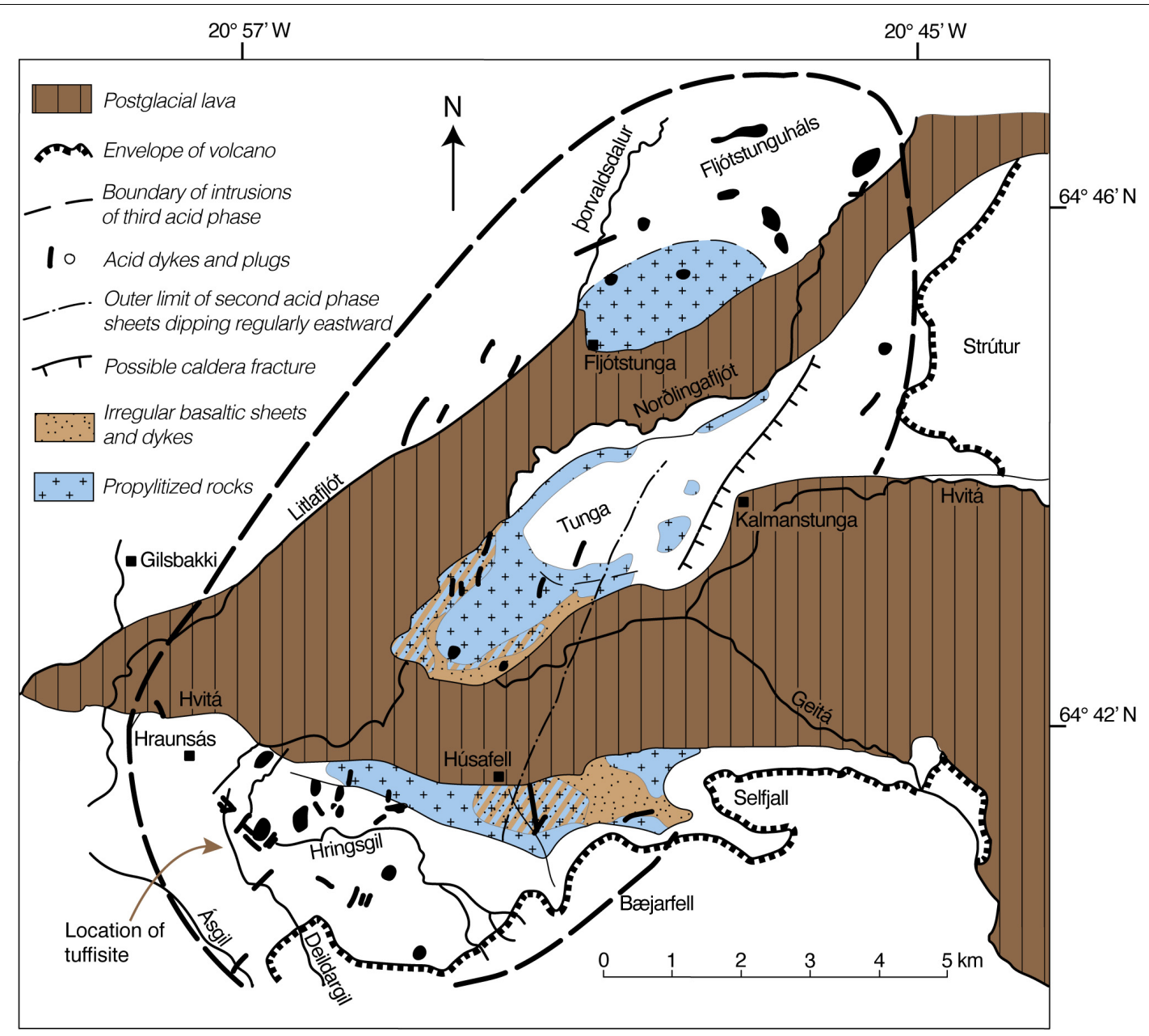

FIGURE 2 | Map of the geology of the Húsafell area with the location of the tuffisite, in Deildargil. Adapted from Sæmundsson and Noll (1974).

of massive glass (black ignimbrite), while the unit above the tuffisite and forming its roof is much more friable, fractured, and devitrified (red ignimbrite; Figure 3; Saubin et al., 2019). The black ignimbrite is laterally heterogeneous, appearing less densely welded to the south. Abundant near-horizontal platy fracturing within the red ignimbrite pre-dated tuffisite formation, and facilitated the detachment and incorporation of red ignimbrite blocks into the tuffisite. The wall rock lithology appears to have controlled the morphology of the tuffisite margin, with a sharp planar contact at the tuffisite base, against the black ignimbrite, and a more irregular upper margin as the tuffisite was guided by and exploited weaknesses in the overlying red ignimbrite (Figure 3). Although the upper margin is not planar, the tuffisite does not form offshoots into the roof rock. The tuffisite is offset by two minor faults along its length, displacing it by about $20 \mathrm{~cm}$, and there are numerous sub-vertical fractures through the tuffisite that also cross-cut the overlying red ignimbrite.

The tuffisite has a well-defined but locally complex internal structure consisting of $0.5-20 \mathrm{~cm}$ thick units aligned roughly parallel to the tuffisite walls (Figure 4). We adopt a strategy for distinguishing individual depositional units that is based on the following characteristics: grain-size, clast composition, colour, internal structure, and the presence of erosion surfaces.

Most units are laterally continuous for several metres, but thinner units seldom extend $>1 \mathrm{~m}$, and such laterally discontinuous units pinch out at the edges after $0.3-1 \mathrm{~m}$. The sequence of units fines upwards from the tuffisite base, but the grain-size increases again immediately above a number of prominent erosive contacts, with material clearly cross-cutting the units underneath. This fining upwards sequence is also interrupted by discontinuous coarse-grained units (Figure 5). All of the units show evidence for a degree of sintering-evidenced by induration-but while some areas show greater sintering, to moderately well-sintered, the degree of sintering does not appear to vary systematically along the tuffisite.

\section{Facies Descriptions}

The different characteristics of the tuffisite units allow them to be divided into facies of different grain sizes, described here in order, moving upwards from the tuffisite base in an overall fining upwards sequence. Individual facies are then divided into subfacies of units, defined by the presence or absence of internal 

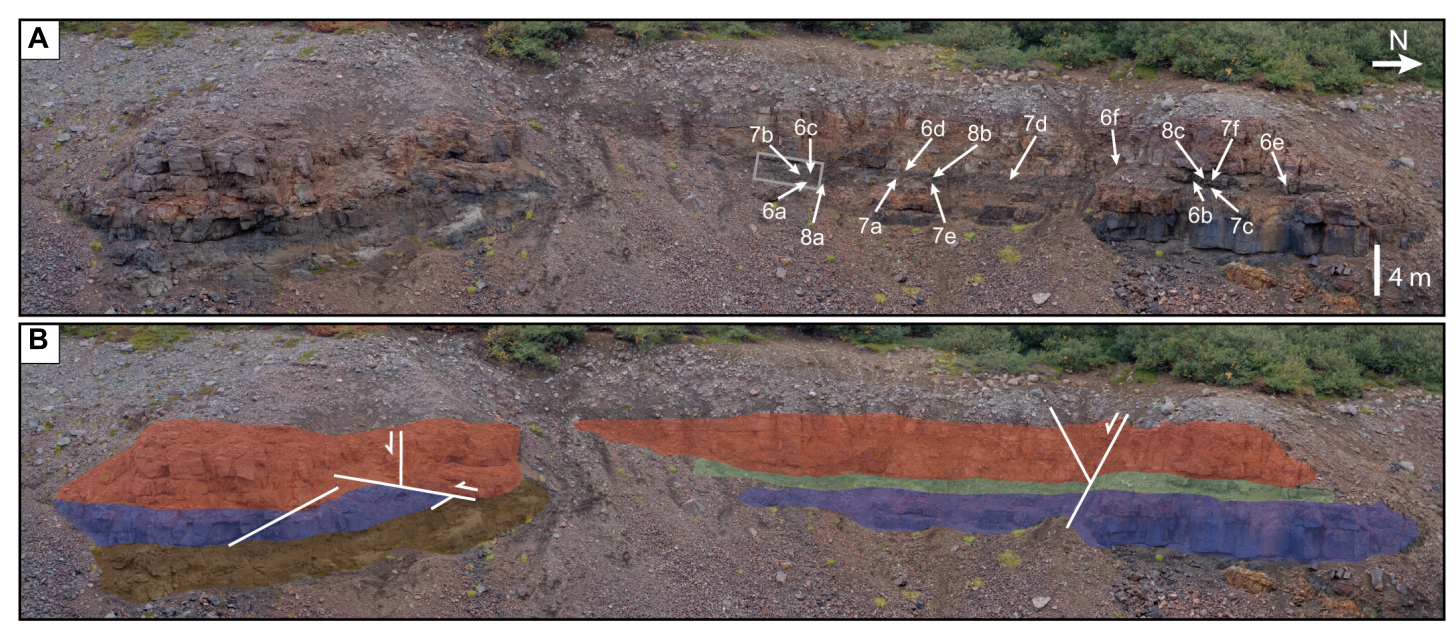

FIGURE 3 | Photograph (A) and interpretation (B) of the intrusive system. The upper red ignimbrite is coloured red, lower welded ignimbrite in blue, the tuffisitic sill in green, and magmatic intrusion in brown. The grey box shows the position of the photograph shown in Figure 4, and labels indicate the position of the photographs in Figures 6-8.
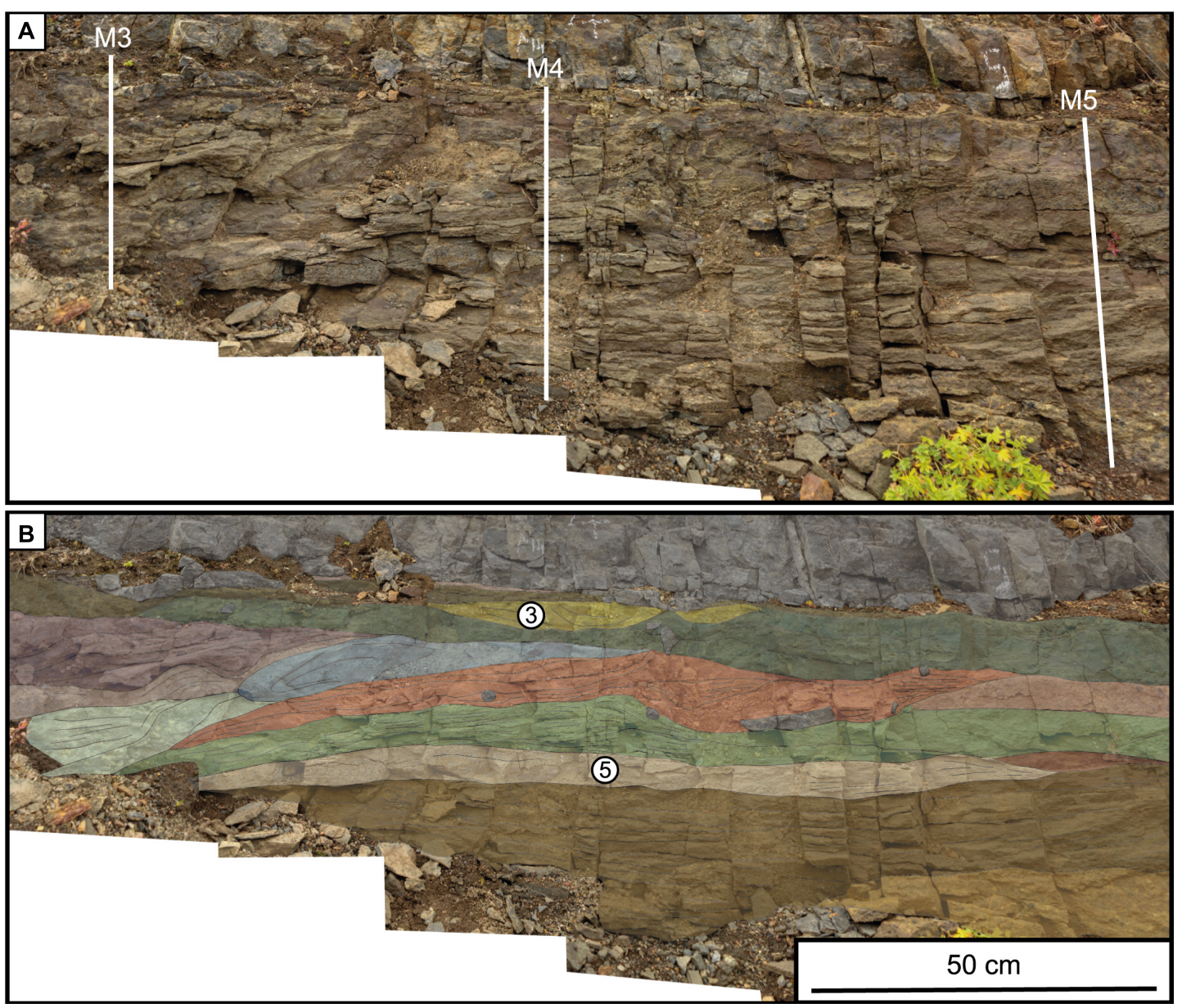

FIGURE 4 | Photograph (A) and interpretation (B) showing a closer view of the tuffisite, which has a clear but complex internal structure consisting of many units M3, M4, and M5 labelled on (A) give the location of the graphic logs shown in Figure 5. Labels 3 and 5 mark examples of Structure 3 (channels) and Structure 5 (fine rimmed sub-horizontal lenses, interpreted as finger-shaped injections in section "Structure 5: Finger-Shaped Injections"). Note how units are dipping toward the S. 


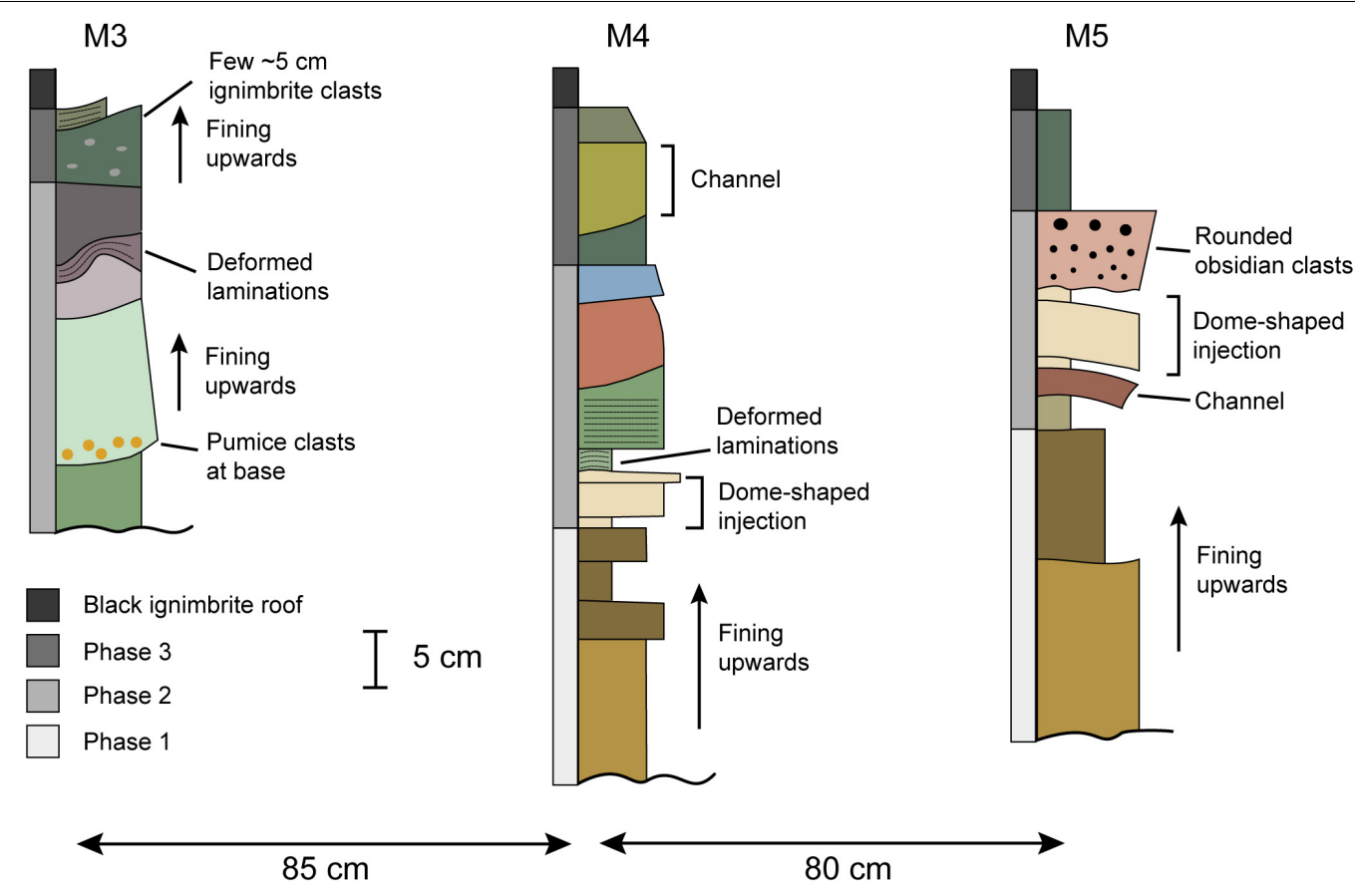

FIGURE 5 Three graphic logs of the tuffisite each spaced about $80 \mathrm{~cm}$ apart. The locations of logs are labelled in Figure 4, and beds are given corresponding colours. The tuffisite is composed of fining upwards sequences, interrupted by coarser laterally discontinuous units. The deposition of units can be separated into three different phases, allowing for an overall model of tuffisite emplacement to be interpreted.

structure. Each facies is named according to the pyroclastic lithofacies naming scheme of Branney and Kokelaar (2002) and the characteristics of each facies within the Húsafell tuffisite are summarised in Table 1.

\section{Massive Lithic Breccia (mIBr)}

At the very base of the tuffisite, where preserved, is a massive $<20 \mathrm{~cm}$ thick breccia unit containing clasts of ignimbrite, derived from the unit below, as well as subrounded clasts of rhyolitic pumice and dense obsidian (Figures 6A,B). This unit forms the base of a $<50 \mathrm{~cm}$ thick sequence of units, each with a finer grain-size than the units beneath. Other massive breccias are found in the upper $25 \mathrm{~cm}$ of the tuffisite and are less laterally continuous as they are cross-cut or truncated by other units.

The units form a spectrum between two end-members of pumice-rich and ignimbrite-rich breccias. The pumice-rich endmember is matrix-supported with $25-30 \%$ clasts, but may be locally clast-supported, with $\leq 50 \%$ clasts, and larger clasts appear more rounded. The ignimbrite-rich end-member is less clast rich, with clasts forming around $20 \%$ of the rock. More details on the componentry of both end-members can be found in Table 1. The clasts show no alignment or arrangement.

\section{Stratified Lithic Breccia (dsIBr)}

Breccia units $<10 \mathrm{~cm}$ thick show alignment of clasts, particularly ignimbrite clasts. These units are typically finer than those of $\mathrm{mlBr}$, with $\leq 2 \mathrm{~cm}$ clasts that are unevenly distributed (Figure 6C). Pumice clasts are typically seen in a greater concentration toward the top of each unit. These breccias are found in the upper $30 \mathrm{~cm}$ of the tuffisite, but are never the uppermost unit. The units can be laterally continuous for several metres but are typically crosscut or truncated by other units, creating erosive upper and lower boundaries.

\section{Massive Lapilli Tuff ( $\mathrm{mLT})$}

The majority of the tuffisite consists of lenticular to laterally persistent, poorly sorted units of lapilli-tuff that form the centre of the tuffisite (Figures 6D,E). These units are usually part of a poorly defined fining upwards sequence, deposited as a series of southwards dipping units that are crosscut by later material. Coarse lapilli also forms discontinuous flat-based units with rounded tops. These massive units vary from about 8$30 \mathrm{~cm}$ in thickness and form a spectrum between pumiceous and ignimbrite-rich end members.

The pumice-rich end-member is almost entirely formed of fine lapilli-sized pumice grains with sparse ignimbrite and obsidian particles, and forms the uppermost unit of the tuffisite, trapped between ignimbrite clasts (Figure 6F). The componentry of a more typical pumiceous unit is given in Table $\mathbf{1}$.

\section{Stratified Lapilli Tuff (dsLT)}

Units of lapilli-tuff found toward the tuffisite centre are often interbedded with thin horizons of finer grained material (Figure 7A). These units are typically $2-10 \mathrm{~cm}$ thick and may be laterally continuous for tens of centimetres or pinch out, forming lenses. Fine to coarse lapilli are mixed with occasional larger clasts to produce moderately to poorly sorted lapilli-tuffs (Figure 7B). 
TABLE 1 | Summary of the different tuffisite facies and their characteristics.

\begin{tabular}{|c|c|c|c|c|c|}
\hline & Facies & & Clasts: & Matrix: & Remarks \\
\hline \multirow[t]{3}{*}{ Lithic breccia } & \multirow[t]{2}{*}{$\begin{array}{l}\text { mlBr- } \\
\text { Massive } \\
\text { lithic } \\
\text { breccia }\end{array}$} & $\begin{array}{l}\text { Pumice- } \\
\text { rich } \\
\text { end } \\
\text { member }\end{array}$ & $\begin{array}{l}20-40 \% \text { rounded, high sphericity pumice } \\
0.2-1 \mathrm{~cm} \text { across. } \\
\leq 5 \% \text { subrounded-angular high sphericity } \\
\text { ignimbrite } \leq 2 \mathrm{~cm} \text { across. } \\
\sim 2 \% \text { rounded-subangular spherical dense } \\
\text { obsidian } \leq 1 \mathrm{~cm} \text { across. } \\
\text { Rare grey lithics } \leq 2 \mathrm{~cm} \text { across. }\end{array}$ & $\begin{array}{l}\text { Yellow-grey, fine lapilli-tuff sized } \\
\text { pumice-rich matrix. } \\
10 \% \text { angular dense obsidian } \\
\text { chips. } \\
\leq 2 \% \text { subangular ignimbrite } \\
\text { chips. }\end{array}$ & $\begin{array}{l}\text { Poorly sorted matrix supported } \\
\text { lithic breccia, clast supported in } \\
\text { places. } \\
\text { Clasts typically show no alignment. }\end{array}$ \\
\hline & & $\begin{array}{l}\text { Ignimbrite- } \\
\text { rich end } \\
\text { member }\end{array}$ & $\begin{array}{l}\sim 20 \% \text { subangular-subrounded ignimbrite } \\
1-2 \mathrm{~cm} \text { across, with aspect ratio } \leq 2 \\
2 \% \text { rounded spherical pumice } \leq 1 \mathrm{~cm} \text { across. } \\
\text { Rare rounded high sphericity vesicular } \\
\text { lithics } \leq 2 \mathrm{~cm} \text { across. }\end{array}$ & $\begin{array}{l}\text { Grey-green, fine lapilli-tuff sized } \\
\text { pumice-rich matrix. } \\
30 \% \text { angular dense obsidian } \\
\text { chips. }\end{array}$ & $\begin{array}{l}\text { Poorly sorted and matrix } \\
\text { supported. Large ignimbrite blocks } \\
\text { up to } 19 \mathrm{~cm} \text { across. }\end{array}$ \\
\hline & \multicolumn{2}{|c|}{ dsIBr-Stratified lithic breccia } & $\begin{array}{l}\text { Clasts unevenly distributed in pockets and } \\
\text { varying from } 5 \text { to } 30 \% \text { of rock. } \\
\leq 30 \% \text { Rounded spherical pumice } \leq 2 \mathrm{~cm} \\
\text { across. } \\
\leq 2 \% \text { Subangular ignimbrite } \sim 0.5 \mathrm{~cm} \text { across, } \\
\text { aspect ratio } \leq 1.5 \text {. }\end{array}$ & $\begin{array}{l}\text { Medium lapilli-tuff sized } \\
\text { pumice-rich matrix. }\end{array}$ & $\begin{array}{l}\text { Ignimbrite clasts are aligned parallel } \\
\text { to tuffisite walls or sub-horizontally } \\
\text { defining cross-stratification. } \\
\text { Contains irregularly shaped pockets } \\
\text { of laminated ash-size material (sT). }\end{array}$ \\
\hline \multirow[t]{3}{*}{ Lapilli-tuff } & \multirow[t]{2}{*}{$\begin{array}{l}\text { mLT- } \\
\text { Massive } \\
\text { lapilli-tuff }\end{array}$} & $\begin{array}{l}\text { Pumice- } \\
\text { rich } \\
\text { end } \\
\text { member }\end{array}$ & $\begin{array}{l}\text { 10-20\% rounded spherical pumice } 1-3 \mathrm{~mm} \\
\text { across. } \\
10 \% \text { subrounded-angular ignimbrite } \leq 2 \mathrm{~mm} \\
\text { across. } \\
\text { Rare grey lithics. }\end{array}$ & $\begin{array}{l}\text { Yellow-brown, fine lapilli-tuff } \\
\text { sized pumice-rich matrix. } \\
5 \% \text { dense obsidian chips. }\end{array}$ & $\begin{array}{l}\text { One unit entirely moderately well } \\
\text { sorted, medium lapilli-tuff sized } \\
\text { pumice grains. More common unit } \\
\text { described here. }\end{array}$ \\
\hline & & $\begin{array}{l}\text { Ignimbrite- } \\
\text { rich end } \\
\text { member }\end{array}$ & $\begin{array}{l}10-30 \% \text { subrounded-angular ignimbrite } \\
\text { clasts } \leq 2 \mathrm{~mm} \text { across, aspect ratio } \leq 1.4 \\
2 \% \text { grey lithics } \leq 1 \mathrm{~cm} \text { across. } \\
\leq 2 \% \text { rounded pumice clasts } 0.5-2 \mathrm{~mm} \text { across. }\end{array}$ & $\begin{array}{l}\text { Grey-green, fine lapilli-tuff sized } \\
\text { pumice-rich matrix. } \\
30 \% \text { angular dense obsidian } \\
\text { chips } \leq 0.5 \mathrm{~mm} \text { across. }\end{array}$ & $\begin{array}{l}\text { Ignimbrite clasts may show } \\
\text { alignment parallel to tuffisite walls. }\end{array}$ \\
\hline & \multicolumn{2}{|c|}{ dsLT-Stratified lapilli-tuff } & $\begin{array}{l}\leq 20 \% \text { rounded spherical pumice clasts in } \\
\text { pockets generally } 2-3 \mathrm{~mm} \text { across, largest } 3 \mathrm{~cm} \\
\text { across. } \\
\leq 5 \% \text { subangular ignimbrite } \leq 5 \mathrm{~mm} \text { across. } \\
\leq 5 \% \text { rounded obsidian } 3 \mathrm{~mm} \text { across. }\end{array}$ & $\begin{array}{l}\text { Pumice-rich with } \leq 20 \% \\
\text { subangular dense obsidian } \\
\text { chips. }\end{array}$ & $\begin{array}{l}\text { Often interbedded with sT. } \\
\text { Ignimbrite clasts aligned parallel to } \\
\text { tuffisite walls. Cross-stratification, } \\
\text { graded beds and laminated lenses. }\end{array}$ \\
\hline \multirow[t]{2}{*}{ Tuff } & \multicolumn{2}{|c|}{ mT-Massive tuff } & $\begin{array}{l}\leq 5 \% \text { rounded-subrounded ignimbrite clasts } \\
\leq 1 \mathrm{~cm} \text { across. } \\
\leq 2 \% \text { rounded pumice clasts } \sim 0.25 \mathrm{~mm} \text { across. }\end{array}$ & $\begin{array}{l}\text { Moderately well sintered } \\
\text { material that weathers red. }\end{array}$ & $\begin{array}{l}\text { Ignimbrite clasts can show some } \\
\text { alignment parallel to tuffisite walls. }\end{array}$ \\
\hline & \multicolumn{2}{|c|}{ sT-Stratified tuff } & $\begin{array}{l}\text { Rare subangular-subrounded ignimbrite clasts } \\
\text { up to } 2 \mathrm{~cm} \text { across, aspect ratio } \leq 1.4 \text {. }\end{array}$ & $\begin{array}{l}\text { Well sorted glassy shards of } \\
\text { pumice and dense obsidian. }\end{array}$ & $\begin{array}{l}\text { Laminated material commonly } \\
\text { showing cross-stratification, graded } \\
\text { beds and soft sediment } \\
\text { deformation. }\end{array}$ \\
\hline
\end{tabular}

The units show a variety of different structures, including cross-stratification with foresets about $5 \mathrm{~cm}$ thick, defined by horizons of finer grained red material and the alignment of ignimbrite clasts. Graded beds of coarse to fine lapilli can be seen in both outcrop and thin-section scale, with both fining and coarsening upwards units (Figures 7C,D). Lenses of lapilli reach $15 \mathrm{~cm}$ in width and coarsen upwards, showing internal laminations, representing the migration of bedforms within the active hydrofracture.

\section{Massive Tuff (mT)}

The finest-grained massive units, which have ash-sized particles deposited in $\leq 5 \mathrm{~cm}$ thick units, are only seen in the upper half of the tuffisite fill, and their friable nature makes the rock prone to erosion. The rock weathers red and consistently appears to be moderately well-sintered. This facies also forms veinlets, with finer-grained margins and coarser centres, that cross-cut the surrounding tuffisite (Figure 7E).

\section{Stratified Tuff (sT)}

The majority of ash-sized material in the tuffisite forms thin ( $\leq 2 \mathrm{~cm}$ thick) beds comprised of many sub-millimetre laminations of darker and finer material. Many of the laminae can be readily followed laterally for $>20 \mathrm{~cm}$, while other laminae crosscut one another or are more lenticular in shape, pinching out after a few centimetres (Figures 7A,C). This facies is often found interbedded with coarser-grained material, forming narrow laminated horizons. Cross lamination is very common, with foresets $\leq 3 \mathrm{~mm}$ thick.

The well-sorted nature of the finely laminated material is apparent in both outcrop and thin section. Glassy shards of obsidian give particles an angular shape. This material contains 

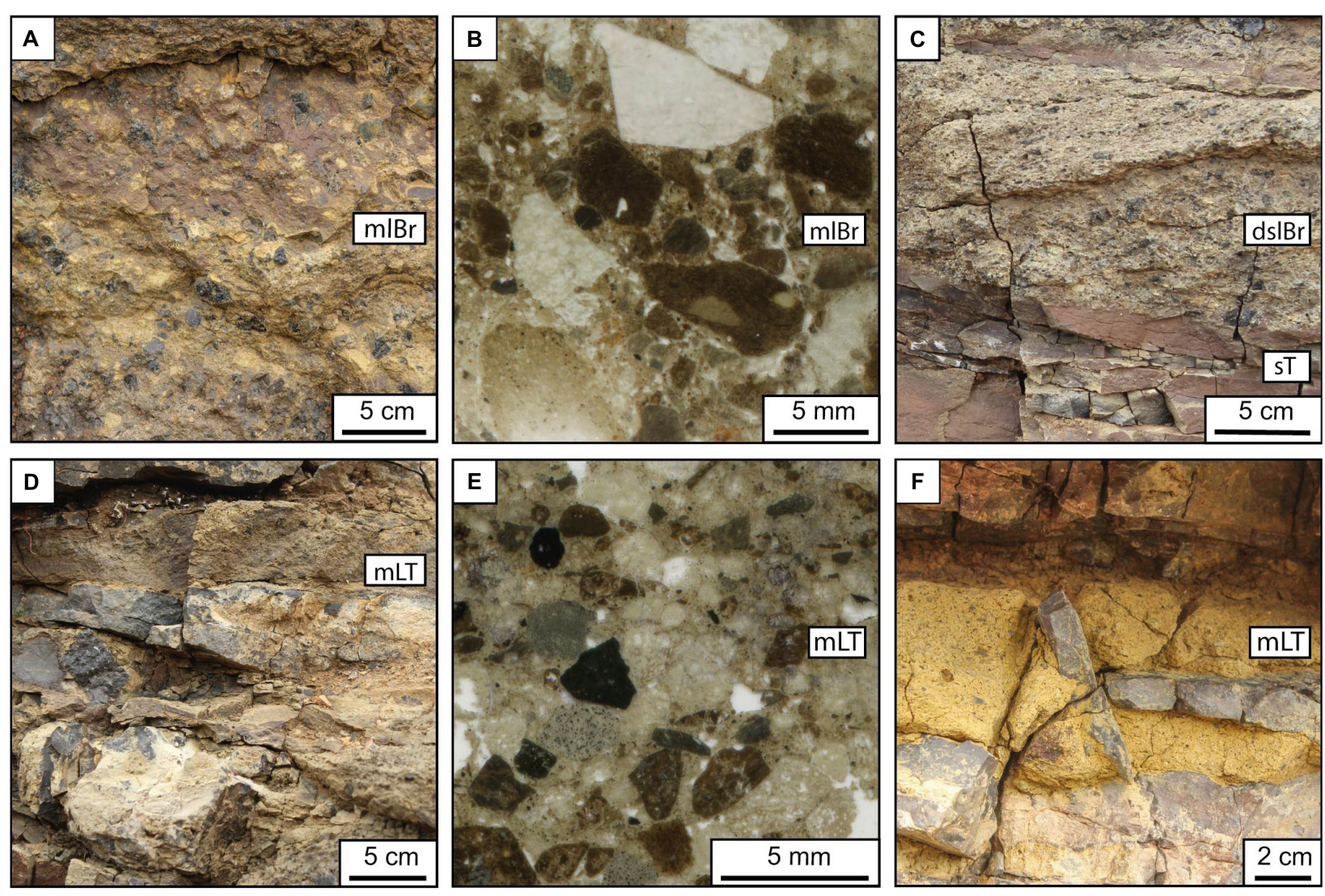

FIGURE 6 | Photographs of different facies of coarse-grained material found in the tuffisite. Labels give the facies present in each image and are also listed in brackets. (A) Massive breccia with pumice and obsidian clasts at the base of the tuffisite (Facies mIBr). (B) Thin section of a massive breccia unit (Facies mIBr). (C) Breccia unit with aligned ignimbrite clasts (Facies dsBr) with laminated tuff beneath (Facies sT) containing a coarser lens of medium lapilli grains. (D) Massive lapilli-tuff (Facies $\mathrm{mLT}$ ) separated from the units beneath by large clasts of ignimbrite. (E) Thin section with structureless units of coarse lapilli grains (Facies mLT). (F) Yellow-orange pumiceous end member of Facies $\mathrm{mLT}$, interfingered between ignimbrite clasts.

far fewer ignimbrite clasts than the coarser material mentioned above. In thin section, particles appear neatly organised into laminae that may grade into one another (Figures 7D,F).

\section{Tuffisite Structures}

The tuffisite contains a variety of structures that preserve key evidence for emplacement processes. Interpretation of these features will provide constraints on the processes occurring during tuffisite formation, and the fluid pressure required for its emplacement.

\section{Structure 1: Entrainment of Clasts and Blocks}

There are a number of $\leq 30 \mathrm{~cm}$ ignimbritic country rock blocks at the tuffisite base, consisting of roof material (Figures 6D,F, 7A, 8A). These elongated blocks are locally balanced on their end, and thus clearly rotated, but the surrounding finer sediment is massive, showing no variations in grain-size or clast distribution. Smaller clasts can show shadow zones, with finer material clearly deposited on the southern side of $\sim 2 \mathrm{~cm}$ ignimbrite clasts.

\section{Structure 2: Internal Veins}

There are numerous places where the tuffisite fill is crosscut by thin veinlets of ash-sized material that do not follow bedding, indicating that they formed later than the main unit they crosscut (Figures 7E, 8B). These features appear to be widespread, visible both in outcrop (veinlets $\sim 3 \mathrm{~cm}$ thick) and in many of the thin sections produced (veinlets $<0.5 \mathrm{~mm}$ thick).

The cross-cutting material is always very fine-grained. In outcrop it often appears to be laminated, although the submillimetre laminations cannot be traced for more than a few centimetres before they are crosscut by another lamination. The margins of the cross-cutting veinlets are very fine, and the material crudely coarsens inwards. This is best seen in thin section (Figures 7E, 8B), where injections have very fine-grained and laminated edges, and where wide enough, then coarsen into fine lapilli-sized material at their centres. The presence of multiple cross-cutting generations of veins indicates a repeated process. There is no visible deformation of the cross-cutting vein walls, which appear sharp, even in thin section. In outcrop, crosscutting veinlets follow sub-vertical fractures for $\leq 20 \mathrm{~cm}$. Veinlets separate units with a very similar appearance. Some vein 

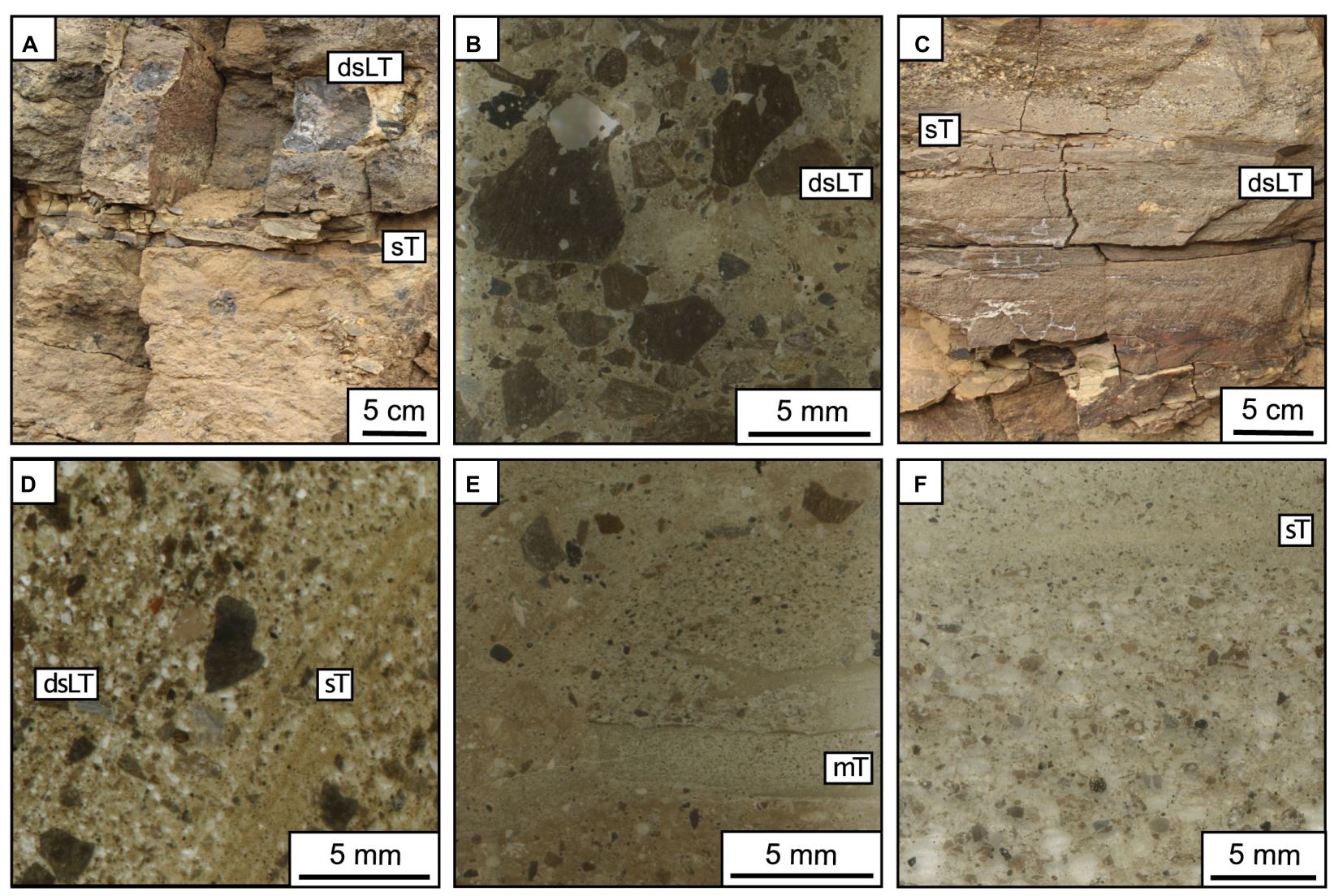

FIGURE 7 | Photographs of the finer grained facies of the tuffisite. Labels give the facies present in each image and are also listed in brackets. (A) Thinly bedded medium grained lapilli-tuff horizons of finer material (Facies dsLT) above large ignimbrite clasts. (B) Thin section of a poorly sorted coarse lapilli-tuff showing some alignment of grains (Facies dsLT). (C) Finely laminated and cross-stratified tuff (Facies ST) with thinly bedded medium grained lapilli-tuff beneath (Facies dsLT).

(D) Thin section of fine grained lapilli-tuff showing grain alignment (Facies dsLT), and finer horizons of ash-sized material (Facies sT). (E) Thin section containing a discontinuous veinlet of massive fine material that coarsens toward the centre (Facies mT). (F) Coarse lapilli-tuff fining upwards into Facies sT.

edge laminations have undergone soft-sediment deformation, forming a C-shape that spans the width of the unit and indicates a flow direction toward the concave edge of the $\mathrm{C}$-shape, or toward the south (Figure 8B).

\section{Structure 3: Channels}

There are discontinuous units found in the upper half of the tuffisite, with rounded bases and approximately flat tops, that pinch out at both ends after 10-30 cm (Figure 4B). The structure is filled with coarse lapilli (Facies dsLT) and fines upwards into finer lapilli and ash-sized material, which is either laminated or deposited in much thinner beds. These units crosscut and erode the underlying units, indicating that their formation occurred during the later stages of infilling the tuffisite.

\section{Structure 4: Interfingered Tuffisite and Ignimbrite Sheets}

The tuffisite passes through a section of ignimbrite that is stratigraphically higher at the northern end of the outcrop, due to the presence of a fault. Here, the tuffisite contains many elongate, sub-horizontal fragments of ignimbrite host rock 2-15 cm thick, with an aspect ratio $\sim 5: 1$, each separated by a thin ribbon of sediment $\leq 10 \mathrm{~cm}$ in thickness (Figures 6F, 8C). The ignimbrite sheets are all positioned in the uppermost third of the tuffisite width, although some ignimbrite blocks are found lower down, typically at the base (Structure 1; Figure 8A). The long axis of each ignimbrite block is aligned largely parallel to the fracture population in the country rock, but with some local rotation, and some larger ignimbrite sheets are fractured vertically into multiple jigsaw-fit fragments arranged in one horizon. Adjacent ignimbrite sheets can also appear displaced by linear subvertical fractures, sometimes filled with particles. In one area, the ignimbrite blocks are arranged at a shallow angle to the tuffisite walls, giving the impression of cross-bedding or imbrication.

The sediment deposited between the ignimbrite sheets, along both horizontal and vertical fractures, is composed of massive lapilli or ash-sized grains (Facies mLT or $\mathrm{mT}$ ). Narrower gaps between ignimbrite clasts are infilled with finer sediment than those where the clasts are more widely spaced. The margins of each ribbon of tuffisite are slightly finer grained than the centre, similar to the internal veins (Structure 2 ). The sediment in the areas containing many ignimbrite clasts shows no internal structure, but prominent sedimentary structures, including cross-bedding and graded beds, do occur 

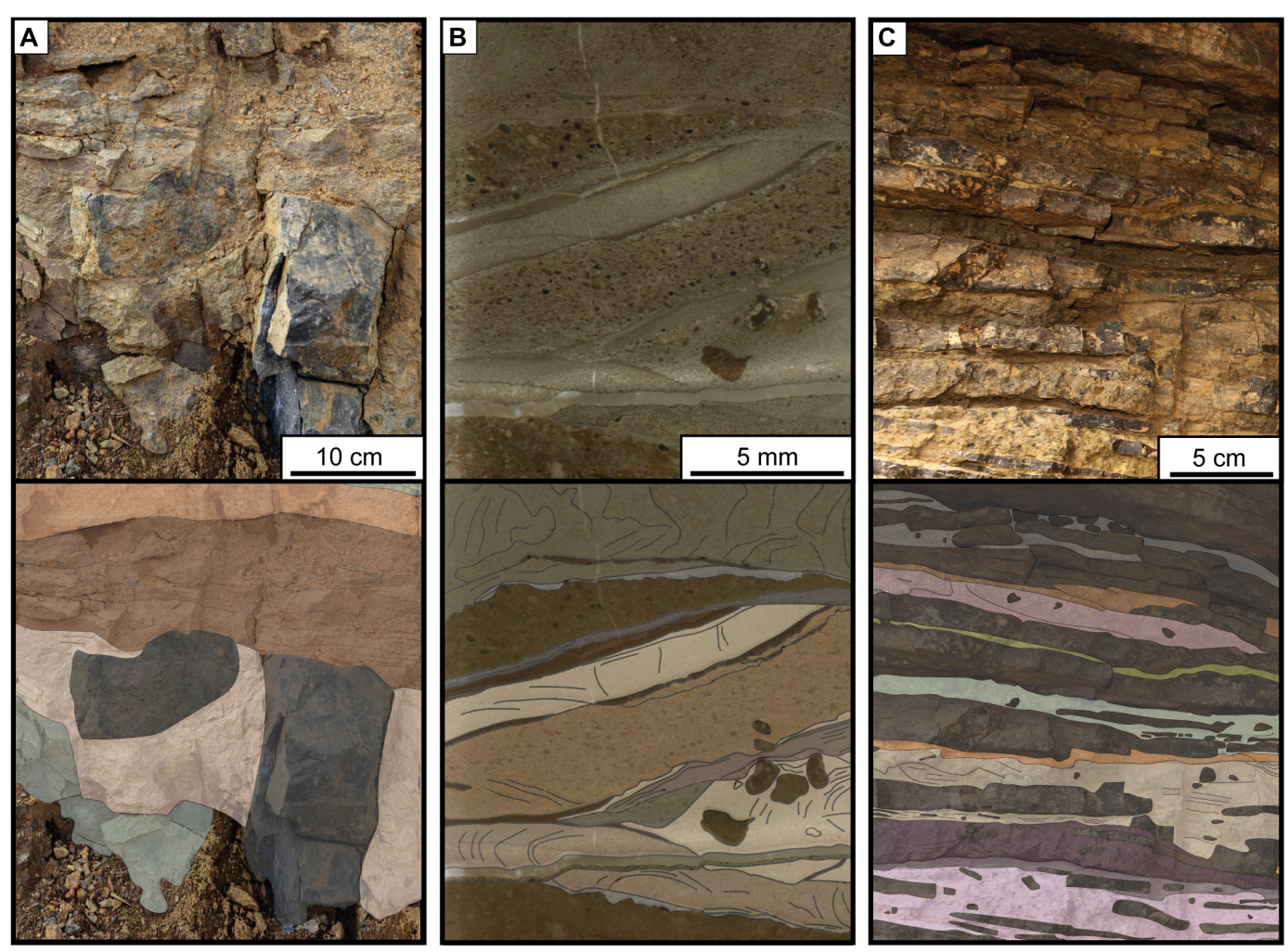

FIGURE $\mathbf{8}$ | Structures seen in the tuffisite fill with photographs (top) and interpretations (bottom). (A) A large block of ignimbrite stood on its end at the base of the tuffisite surrounded by massive sediment (Structure 1). (B) A thin section with particle-filled veinlets that have finely laminated material at their walls and a coarser massive centre (Structure 2). (C) Ribbons of tuffisite interfingered with ignimbrite sheets (Structure 4).

at the tuffisite base, where ignimbrite clasts are absent (Facies dsLT).

\section{Structure 5: Fine Rimmed Sub-Horizontal Lenses}

Some units of massive, coarse to medium lapilli (Facies mLT) are discontinuous, continuing for a few metres before gradually pinching out laterally at both ends (Figure 4B). These units are found in the centre of the width of the tuffisite and, while they feature frequently in the main tuffisite, examples are less apparent where the tuffisite is interfingered with ignimbrite sheets at the northern end of the outcrop. These units are typically $\sim 20 \mathrm{~cm}$ thick at their central thickest point and have a flat base and a domed top that deforms the overlying clastic vein fill. The shape of these structures in $3 \mathrm{D}$ is not visible in outcrop. The overlying laminated material typically has laminations that are deformed, dipping toward the edges of the underlying lens. Occasionally these units are non-conformable, sitting on an erosive surface that crosscuts bedding in the unit beneath.

The edges of the structure are composed of ash-sized material, deposited in laminations that are parallel to the unit edge (Facies sT), even where it pinches out laterally. Here, the laminations form concentric curves on the unit edge. Toward the centre of the unit the material coarsens, over a distance of $10 \mathrm{~cm}$, to medium lapilli. The centre contains $\leq 2 \mathrm{~cm}$ clasts of ignimbrite and obsidian and lacks internal structure.

\section{INTERPRETATION}

The tuffisite consists of a number of units, which can be divided into facies based on their grain-size and internal structure, and contains structures such as channels, lenses and internal veins (section "Field Observations"). These features preserve key evidence for emplacement processes, recording fluctuations in the fluid pressure and particle volume fraction of the suspending fluid.

\section{Direction of Fluid Flow}

The tuffisite consists of multiple units separated by erosion surfaces and, while the units are mostly horizontal, crosscutting relationships indicate how the tuffisite may have evolved through time. The southwards dip of units in the middle of the tuffisite, along with cross-stratification, suggests that the injected fluid flowed southwards, eroding the underlying material and depositing multiple dipping units (foresets) to produce a structure that migrated laterally over time (Figures 4B, 9). Field evidence suggests that a subsequent pulse of higher velocity fluid eroded the top of this structure, followed by the deposition of the unconformable overlying unit. Shadows behind clasts and softsediment deformation in internal injections also suggest fluid flow toward the south. In some areas of the outcrop, the fluid flow direction interpreted from cross-stratification is inconsistent, indicating a range of fluid flow directions. This inconsistency 

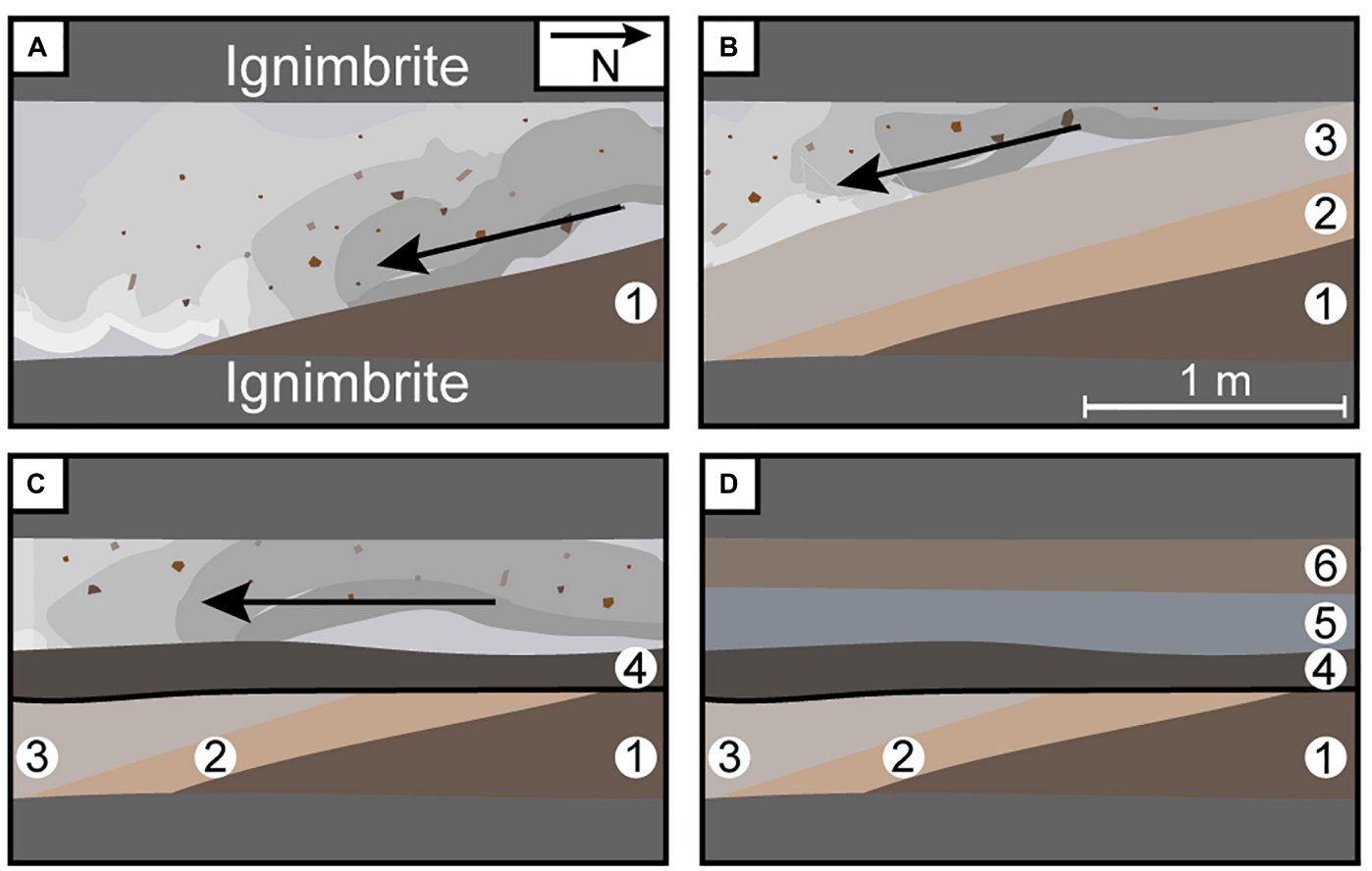

FIGURE 9 | Schematic showing the deposition of southwards dipping units in the tuffisite. (A) Fluid flow toward the south deposits a tuffisite unit (1) with a shallow angle. (B) The next tuffisite units (2 and 3) are deposited above, also dipping at a shallow angle to the south, producing a laterally migrating structure. (C) An increase in fluid velocity, driven by a fluctuation in fluid pressure, allows the previous material to be eroded. The next tuffisite unit (4) is unconformably deposited above.

(D) The final tuffisite units (5 and 6$)$ are deposited.

could perhaps be explained by backflow, potentially driven by fluid pressure variations as different fluid flow pathways become blocked, or forward-flow with waxing or waning velocity producing eddies.

\section{A Record of Fluid Pressure Fluctuations}

Units of varying grain sizes and sedimentary structures inside the tuffisite fill can be interpreted as records of changes in the local velocity of the fluid flowing through the fracture, controlled by spatial and temporal variations in the fluid pressure gradient (Cosgrove, 2001; van der Meer et al., 2009; Phillips et al., 2013). These fluctuations in fluid pressure could be produced externally, controlled by the pressure source, or internally, controlled by processes occurring within the fracture itself.

Volcanic eruptions are rarely steady-state, and so the input of fluid from the unsteady volcanic conduit will be necessarily transient and varying on different timescales. On the longest timescale of days to weeks, the fluid pressure will decrease from a maximum close to the onset of the eruption to lower values as magma discharge wanes. The progressive opening of pathways, for example propagating fractures to shallower depths, will increase fracture volume, lowering the fluid pressure on a timescale of seconds to hours. At the shortest timescale, instabilities within the volcanic conduit, due to unsteady flow, would be able to produce fluctuations in fluid pressure with a timescale of seconds. Fluid pressure fluctuations at each of these timescales will be recorded by the facies and structures of the tuffisite fill.
Even if the source pressure were theoretically constant, internal processes acting within the hydrofracture would still result in fluid pressure fluctuations (Perkins and Kern, 1961). Instabilities in fluid flow can be spontaneously generated within the hydrofracture, producing fluid pressure oscillations that would be superimposed on the fluid pressure variations generated externally. Variations in the width of a hydrofracture along its length could locally alter the fluid pressure (Perkins and Kern, 1961), and the deposition and sintering of particles can clog fluid pathways, lowering the permeability (Farquharson et al., 2017; Heap et al., 2019; Kolzenburg et al., 2019) and therefore changing the hydraulic transport properties of the system. Changes in the fluid pressure gradient along the fracture produce local fluctuations in flow velocity, leading to spatial and temporal changes in (1) erosion when the local fluid velocity is relatively high, (2) deposition when the local fluid velocity is relatively low, and (3) bypassing flow at intermediate flow velocities leading to neither erosion nor deposition. Deposition within the hydrofracture will reduce the space available for fluid flow, locally increasing the fluid pressure until a fluid velocity is reached that can erode the recently deposited sediment (Kern et al., 1959). Once erosion opens more space to accommodate fluid flow the fluid pressure gradient will fall, and so will the fluid velocity, resulting in renewed deposition. In this way, the fluid velocity inside the fracture will always fluctuate. If the source pressure is constant, then these fluctuations may occur around an equilibrium value, at which sediment is not eroded and particles being carried by the fluid 
are not deposited but transported through the hydrofracture (Kern et al., 1959).

Based on the reasoning explored above, there are three possible origins of the fluid fluctuations recorded by the sedimentary fill within the tuffisite at Húsafell: (1) the source pressure was broadly steady, but instabilities within the tuffisite itself could still produce fluid pressure oscillations; (2) the source pressure was unsteady but waning, leading to fluid pressure oscillations, superimposed on an overall depositional fill; and (3) the source pressure waxed and waned through time, producing a more complex fill formed by deposition then erosion and re-working of sediment that would perhaps contain little systematic variation. The potential magnitude of the pressure fluctuations generated by these different origins is unclear, preventing individual facies changes or structures within the tuffisite from being linked to fluid pressure fluctuations of one particular origin.

Fluctuations in the fluid pressure create the conditions of erosion and deposition needed to produce sedimentary structures, and the presence or absence of structures in different units additionally reflects the particle concentration of the transporting fluid. Some units (facies dslBr, dsLT, and sT) display complex structures such as cross-bedding, laminations, and graded beds, while other units (facies $\mathrm{mlBr}, \mathrm{mLT}$, and $\mathrm{mT}$ ) display less-structured, massive features. These differences can be interpreted as the result of low vs. high particle concentration in the bypassing flow, leading to laminated vs. massive deposits [e.g., indicate deposition from a fluid with a low particle concentration, rather than due to the injection of a slurry with a high particle concentration, which is inferred for massive units (facies mlBr, mLT, and $\mathrm{mT}$; Sparks, 1976; Allen, 1982; Walker, 1984)], or as the result of highly unsteady vs. sustained and steady current conditions at the time of deposition (e.g., Branney and Kokelaar, 2002).

\section{Interpretation of Structures \\ Structure 1: Entrainment of Clasts and Blocks}

Large clasts and blocks of the surrounding ignimbrite within the tuffisite would have required a high fluid velocity to be transported along the fracture, and indicate the minimum width of the open fracture system. One of these ignimbrite blocks (Figure $\mathbf{8 A}$ ) is positioned on its narrow end, and so is likely to have been rolled along the base of the fracture before being deposited in that orientation. There is a notable lack of variation and structure in the surrounding units of breccia and coarse lapilli, even adjacent to large obstructing objects in the flow path such as the ignimbrite block. This is further evidence that at times the fluid had a high particle concentration, giving it the characteristics of a mass-flow or slurry (Fisher et al., 1983; Branney and Kokelaar, 2002), while at other times the formation of cross-lamination indicates that the particle concentration was significantly lower.

\section{Structure 2: Internal Veins}

Cross-cutting units of massive material, often bordered by material of a smaller grain-size, are interpreted as injections (Figure 8B). These features appear similar to many centimetre scale hydrofractures reported in glacial environments and sand injectites, with fine-grained edges and a coarser centre (van der Meer et al., 2009; Hurst et al., 2011; Phillips et al., 2013; Phillips and Kearsey, 2020). We interpret the structures as smaller-scale hydrofractures injected into the earlier formed fill of the larger tuffisite, representing self-intrusion. Where the earlier deposited fill has gained cohesion, due to compaction and the sintering of tuffisite material, an increase in fluid pressure can exceed the overburden and strength of incipiently sinter-bonded clastclast contacts, enabling the fracturing of this fill and injection of an internal vein.

Such pressurized fluid injection and self-intrusion opens a new more permeable pathway through the earlier tuffisite fill, leading to localised fluid flow and eventually particle deposition. The fine-grained material is the easiest to mobilise and is the first injected into the new fracture, filtering into the host rock and sealing any fluid pathways (Phillips and Kearsey, 2020), similar to the formation of mudcake during well drilling (Ferguson and Klotz, 1954; Dewan and Chenevert, 2001). Once the fracture has widened coarser material can be injected, with variations in fluid pressure as the fracture fills producing laminations that can be later deformed by fluid flow, as is seen in both sand injectites and hydrofractures in glacial environments (e.g., Scott et al., 2009; Ravier et al., 2014).

The fractures have well-defined straight edges, indicating that the unit overlying the injection must have been sufficiently compacted and consolidated to behave as a cohesive unit. This may reflect sintering-driven strengthening (e.g., Tuffen and Dingwell, 2005; Wadsworth et al., 2016). Cross-stratification indicates that the fluid particle concentration must have been relatively low, with particles deposited inside a void rather than as part of a slurry (Tuffen et al., 2003; Phillips et al., 2013). Even these small injections appear to have involved deposition from multiple pulses of material, generating beds and fine laminations.

\section{Structure 3: Channel Structures}

Channel structures in the Húsafell tuffisite represent preferential fluid pathways. Channels indicate that pulses of material are not only injected within previously deposited material, but can also erode the underlying material as would be expected in a normal sedimentary sequence (Figure $4 \mathrm{~B}$ ). This ability to erode represents large local variations in fluid velocity, so that the fluid can transport previously deposited particles. As the unit beneath sinters and strengthens through time it will become more difficult to erode, and channel formation will therefore only be possible if the pre-existing material is not significantly sintered. Channel formation will be favoured where the frequency of injections is high, allowing for rapid erosion before material can sinter, or the cooling rate is high (fast), preventing significant sintering from occurring. To produce the channel structures in the tuffisite, the fluid velocity must initially be sufficient to erode material. A slowing of the fluid flow then allows for deposition on the erosion surface, forming multiple dipping layers (Branney and Kokelaar, 2002). After another period of erosion, unconformable overlying beds could be deposited. 

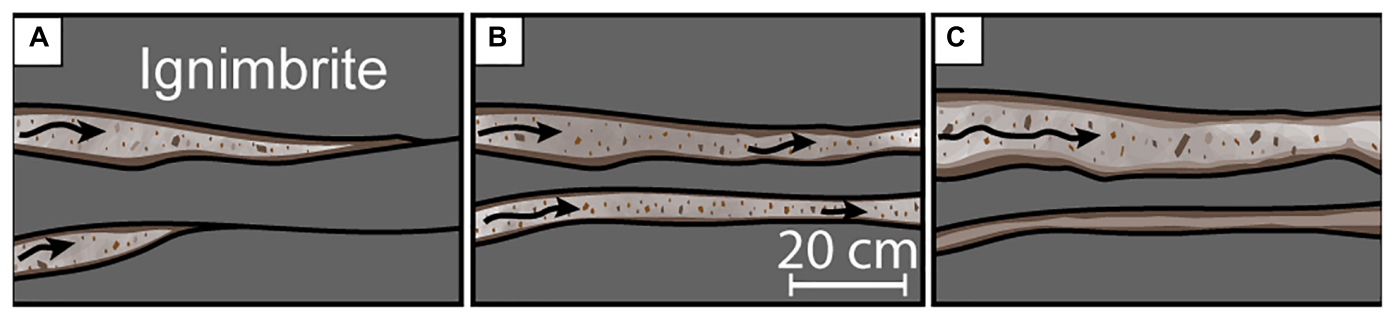

FIGURE 10 | Schematic showing the formation of interfingered tuffisite veins and sheets (Structure 4). (A) The fluid opens multiple pathways along weaknesses in the ignimbrite, allowing for fluid flow and particle deposition in each fracture. (B) Material is deposited inside each fracture, with fine material first deposited at the edges and coarser material toward the centre. (C) Fractures are interlinked, and through time dominant fluid pathways form, widening certain fractures while others narrow and become clogged with particles.

\section{Structure 4: Fracking Through Ignimbrite}

The tuffisite is seen to form multiple pathways through ignimbrite blocks to the north of the fault guided gully (Figures 6F, 8C). The ignimbrite fragments are aligned, and long segments have been vertically fractured into shorter tabular blocks that form horizons of ignimbrite clasts. The preferential shape alignment of the blocks, made of the roof material, suggests they did not simply fall on to the underlying sediment once separated, as this would trigger greater disaggregation and reorganisation of the ignimbrite clasts. Instead, we infer that tuffisitic fluid injection within the ignimbrite exploited and opened pre-existing sub-horizontal fractures, thus separating the rock into multiple tabular fragments, between which particles were then deposited, similar to mud-rafting seen in sand injectites (Figures 10A,B; Duranti and Hurst, 2004; Scott et al., 2009). The ignimbrite fragments essentially host small tuffisites within the larger tuffisite.

The fluid pathways between ignimbrite blocks are considered to have formed a network that shifted through time as new fractures opened or pathways became clogged with material. Larger grains would be unable to pass through initially narrow pathways, filtering material until wider dominant fluid pathways were developed (Figure 10C). Although the exact timing is unknown, we consider that these pathways formed as fluid pressure increased at a late stage of tuffisite evolution, when sintering-driven pathway clogging reduced permeable gas escape, driving the opening of new fracture pathways within the overlying ignimbrite. Alternatively, if opened as the tuffisite formed, the structure could represent early pathways that were later refined into a more dominant fluid pathway at the base of the tuffisite.

The tuffisite has fractured multiple pathways through the overlying ignimbrite at only this location, although high aspect ratio blocks of ignimbrite locally occur elsewhere within the tuffisite. The prevalence of fluid pathways in this location may stem from an abnormally high fracture density in the ignimbrite close to the fault, which is only a few metres to the south (Figure 3).

\section{Structure 5: Finger-Shaped Injections}

Massive units of sediment, forming structures with a flat base and rounded top, which pinch out laterally, represent larger injections into the surrounding sediment, $\leq 1 \mathrm{~m}$ in length, which lifted and deformed the units above (Figure 4B). Under conditions in which the interface between two tuffisite units is the pathway of least resistance, high fluid pressure may open this interface and permit further fluid injection, with sediment deposition (Figures 11A,B). The mostly massive structure of the injected material suggests that the fluid had a relatively high particle concentration. As space was opened the fine-grained material was injected, coating the fracture walls (Ferguson and Klotz, 1954; Dewan and Chenevert, 2001), before the coarser-grained material was injected, forcing the fracture open further (Figures 11C,D).

\section{A Model for Tuffisite Emplacement}

We can combine our observations of sediment characteristics and structures to build an overall model for the emplacement of the tuffisite (Figure 1). The southwards dip of units and sedimentary structures, such as cross-stratification, suggest a roughly southwards direction of fluid flow (Figures 4, 9). The presence of multiple erosion surfaces along the length of the tuffisite is evidence for multiple fluid pulses, which have eroded material beneath and deposited coarser material above (Figure 4B).

Gas and pyroclastic material would have fractured a pathway toward the surface until stalled by the strong and densely welded black ignimbrite, requiring a greater fluid pressure to fracture through. The ascending gas and ash may have reached a great enough fluid pressure to fracture the unit, or exploited an easier pathway, perhaps travelling around the edges of the black ignimbrite unit or fracturing the less densely welded section to the south. Once at the base of the weaker and friable red ignimbrite, the pre-existing sub-horizontal fractures would facilitate horizontal propagation rather than further ascent. As the pre-existing fractures were widened, ignimbrite blocks were detached from the tuffisite walls to produce a single fluid pathway, along which particles were deposited.

The evolutionary model established for the emplacement of the Húsafell tuffisite can be divided into three phases.

\section{Phase 1}

Phase 1 is characterised by laterally extensive units that are present along nearly the whole length of the tuffisite $(\sim 40$ $\mathrm{m})$. The laterally extensive, massive conglomerate at the base of the tuffisite was deposited first, as a fluid of high particle concentration was injected along the length of the newly opened 


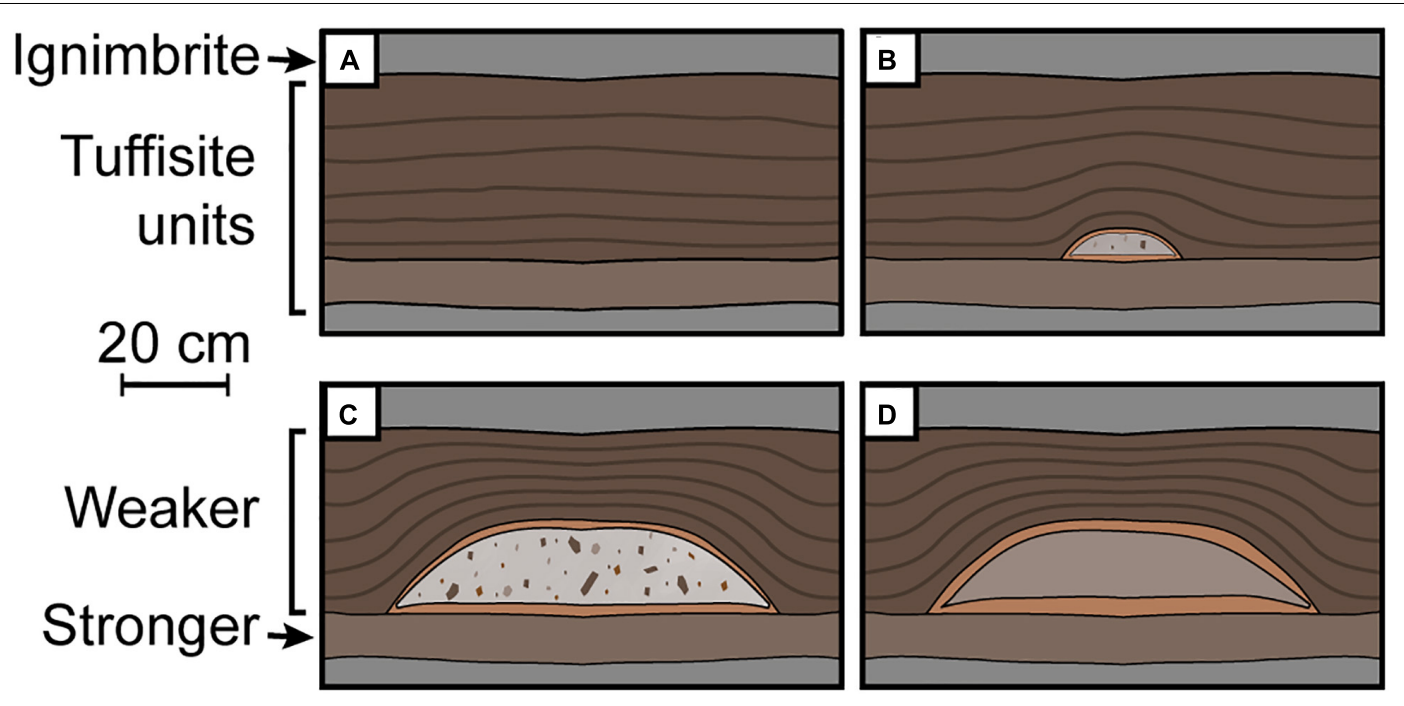

FIGURE 11 | Schematic showing the formation of fine rimmed subhorizontal lenses (Structure 5) as finger-shaped injections. (A) Fluid flowing perpendicular to the plane of the outcrop opens a pathway between a stronger and weaker unit. (B) The widening of the fluid pathway is accommodated by deformation of the weaker material above, forming an intrusion with a domed top and flat base. (C,D) Material is deposited inside the intrusion, with fine material deposited first, forming the margins, and coarser material deposited at the centre.

or propagating fracture, incorporating blocks detached from the country rock (Structure 1; Figures 8A, 12). Gradual reduction in fluid pressure and thus flow velocity led to the deposition of finer grained, interbedded lapilli-tuffs and tuffs, and the deposition of an overall fining-upwards tuffisite sequence (Figure 5). Structures such as cross-lamination and soft-sediment deformation in some of these units represent a drop in the particle concentration of the fluid, allowing for the formation of sedimentary structures.

\section{Phase 2}

A new higher velocity fluid pulse produced an erosion surface above the Phase 1 fining upwards sequence, before depositing a similar sequence, which fines upwards from a breccia (basal lag) to lapilli and ash-sized grains (Figures 5, 12). The units of this second pulse are less laterally extensive, and the increase in internal structures represents deposition in a more openended and wider fracture, from a fluid of a lower particle concentration. Increased erosion and reworking of material led to channel formation (Structure 3; Figure 4B) and southwards migrating units (Figure 9). Internal injections (Structure 2; Figure 8B) indicate how local increases in fluid pressure opened new pathways in the surrounding sintering sediment.

\section{Phase 3}

Phase 3, the final main pulse of material, was deposited above another erosive surface (Figure 12). A lower fluid velocity deposited material as laterally extensive, laminated lapilli-tuffs and tuffs (Facies dsLT and sT; Figure 5). Filling of the open space with material demanded the creation of new pathways, made possible by the increasing fluid pressure. Weaknesses in the overlying ignimbrite were exploited, opening more space and producing ribbons of tuffisite interfingered with country rock (Structure 4; Figures 8C, 10). Where the tuffisite was still hot enough to viscously deform, finger-shaped injections provided another method of opening additional space (Structure 5 ; Figures 4B, 11).

\section{DISCUSSION}

\section{Constraints on Tuffisite Emplacement Conditions}

To open a hydrofracture, the fluid pressure must be great enough to overcome the lithostatic pressure $P_{L}$, induce tensile failure in the surrounding coherent material by overcoming the tensile strength $P_{T}$, and widen the hydrofracture by elastically deforming the surrounding material requiring pressure $P_{W}$. Inelastic deformation is possible but not considered here as there has been no visible deformation of the fracture walls. The required fluid pressure is therefore

$$
P=P_{T}+P_{L}+P_{W}
$$

where $P_{L}$ is calculated using $P_{L}=\rho g h$, with $\rho$ representing the density of the overlying material, $g$ acceleration due to gravity, and $h$ the depth of the hydrofracture from the Earth's surface. As injections occur along pre-existing weaknesses such as unit contacts or fractures, the value of $\mathrm{P}_{\mathrm{T}}$ is very small compared to $\mathrm{P}_{\mathrm{L}}$ and $\mathrm{P}_{\mathrm{W}}$, and so is not considered in pressure estimates below. $P_{W}$ can be given in terms of the fracture width, $W$, and fracture length, $L$, as (Gudmundsson, 1983)

$$
P_{W}=\frac{E}{2\left(1-v^{2}\right)} \frac{W}{L}
$$




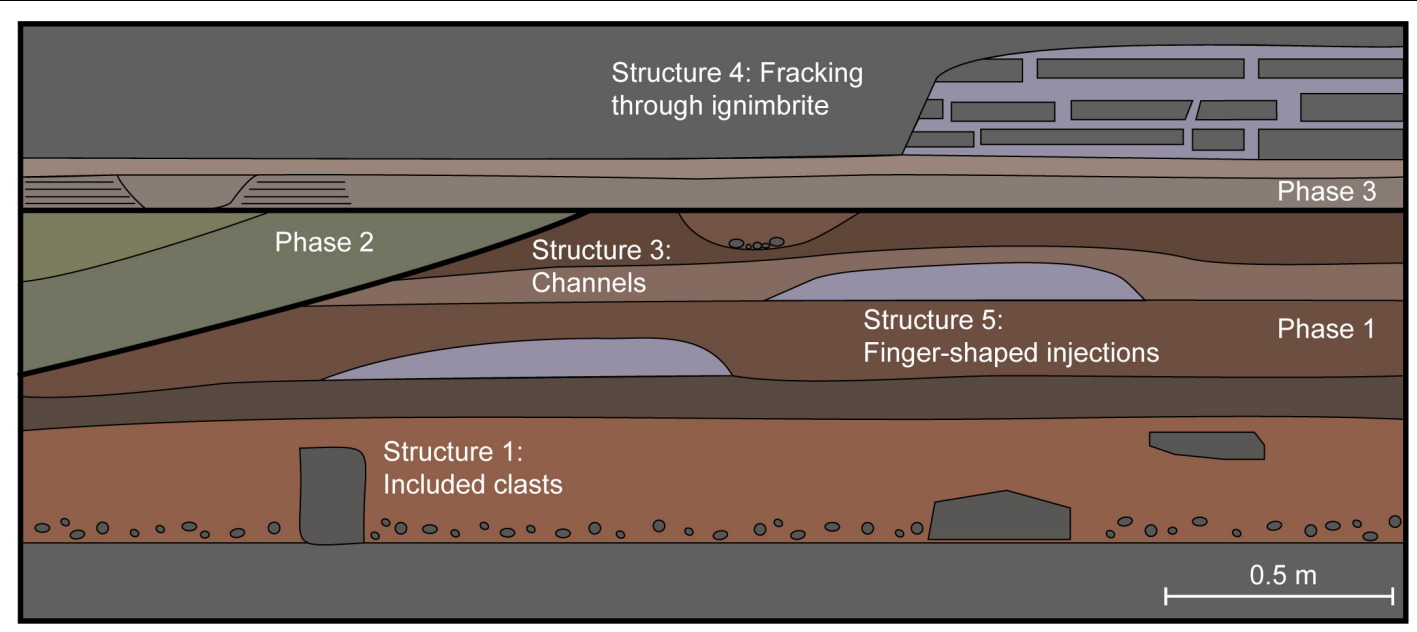

FIGURE 12 | Schematic showing the different phases and structures in the tuffisite fill. Phase 1: A laterally extensive fining upwards sequence is deposited, containing large ignimbrite clasts (Structure 1) separated from the country rock. Phase 2: Fining upwards sequences are deposited unconformably above Phase 1, in more localised units, to form structures such as channels (Structure 3) and cross-lamination. Phase 3: Laterally extensive tuffs and lapilli-tuffs are deposited at the top of the tuffisite. As fluid pressure increases material fractures off blocks of ignimbrite from the tuffisite roof (Structure 4) and forms finger-shaped injections at the tuffisite centre (Structure 5).

where $v$ is Poisson's ratio, and $E$ is the Young's modulus. If $P_{T}$ is negligible, then $P_{W}$ represents the overpressure (pressure in excess of the ambient $P_{L}$ ) required to open a fracture.

If we assume that the country rock overlying the tuffisite has an average density akin to intercalated lithofacies of pyroclastic, welded, and lava deposits typical of the rhyolitic central volcanoes of Iceland (Ágústsdóttir et al., 2011), we can take an approximate density of $\rho=\rho_{0}(1-\phi)$, where $\rho_{0}$ is the density of the solid components and $\phi$ is the average porosity of the overburden. Approximate values might be $\rho_{0}=1800 \mathrm{~kg} \cdot \mathrm{m}^{-3}$ for rhyolite, and $\phi=0.3$ for volcanic sequences: $\rho=1260 \mathrm{~kg} \cdot \mathrm{m}^{-3}$. The tuffisite depth below the surface can be estimated as $h=500 \mathrm{~m}$ via magmatic water concentration in glassy intrusion margins (McGowan, 2016). Taken together, this leads to constraint of $P_{L} \approx 6.2 \mathrm{MPa}$.

In order to calculate the $P_{W}$ component, we must estimate the scales of the tuffisite $W$ and $L$, and the properties of the country rock $\nu$ and E. Regardless of porosity, the Poisson's ratio for volcanic rocks is relatively tightly constrained with $90 \%$ of available data lying within the bounds $0.10<\nu<0.35$. $v=0.21$ can be found for a tuff with $\varphi=0.16$ porosity (Özsan and Akn, 2002), which is also the average of a wide range of measurements using a range of volcanic rocks with porosities from 0.01 to 0.2 (see Heap et al., 2020). Therefore, in this study, we take $\nu=$ 0.21 . To estimate $E$, Gudmundsson (1983) assumed that $E \approx E_{d} / 2$, where $E_{d}$ is the dynamic Young's modulus, given by

$$
E_{d}=\frac{V_{p}^{2}(1+\nu)(1-2 \nu) \rho}{1-\nu} \approx 2 E
$$

where $V_{p}$ is the p-wave velocity of the host rock. Estimates of $V_{p}$ for porous volcanic rock are $V_{p}=1575 \mathrm{~m} . \mathrm{s}^{-1}$ (for $\phi=$ 0.3; Al-Harthi et al., 1999; Vasseur et al., 2016). These constraints lead to $E \approx 1.4 \mathrm{GPa}$. Alternatively, in a review of data for the
Young's modulus of volcanic rocks, Heap et al. (2020) find that the majority of the available data for tuff has an arithmetic mean value of $E=2.4 \mathrm{GPa}$ and the majority of the data for tuff materials occur in a moderate-to-high porosity cluster with an arithmetic mean of $E=1.7 \mathrm{GPa}$. This leaves us to find characteristic values of $W$ and $L$.

The structure of the Húsafell tuffisite is interpreted as a record for fluid pressure fluctuations through time. Using Equation 1 and the constraints provided above, we can estimate the fluid pressure required for tuffisite formation and constrain the maximum overpressure reached by the fluid pressure fluctuations. We compare the pressure required to open the crack hosting the Húsafell tuffisite for two contrasting endmember scenarios. The single-shot model involves the opening of the fracture to maximum width in one pressurisation event, and implies rapid deposition of the whole tuffisite fill width in a single fluid injection event, as a single proppant pulse within a fully dilated (0.9 m-thick and $40 \mathrm{~m}$-long) fracture (Figure 1). The pulsed emplacement model involves sequential injection of a number of thinner units, with multiple sediment pulses within a partially dilated fracture. While the field evidence of continuous margin-parallel deposits implies that the pulsed model still involves a 40-m long fracture, the width of each sequential opening event may be significantly smaller than the tuffisite width.

The single-shot model demands significant elastic deformation of crack walls, and requires an overpressure of $16 \lesssim P_{w} \lesssim$ $29 \mathrm{MPa}$ (lower and upper bound for $E=1.4$ and $E=2.4 \mathrm{GPa}$, respectively; Figure 13). Such a high pressure is much greater than the $2 \mathrm{MPa}$ overpressure predicted at $500 \mathrm{~m}$ depth for a conduit of width $30 \mathrm{~m}$ and an initial water concentration of $4.6 \mathrm{wt} \%$ (Degruyter et al., 2012), similar to the $\sim 5 \mathrm{wt} \%$ water measured in Icelandic rhyolites at Torfajökull (Owen et al., 2013). The model by Degruyter et al. (2012) predicts an overpressure of 


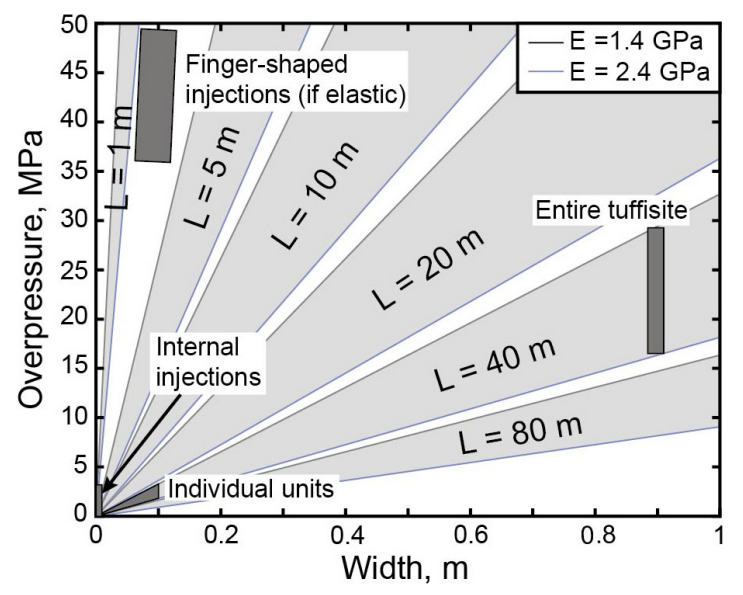

FIGURE 13 | The fluid overpressure required to open tuffisites as a function of fracture width, according to Eq. 2, for different fracture lengths (Gudmundsson, 1983). Plotted pressure fields show the required fluid overpressure to form the tuffisite as a single pulse, or as many individual units, and to form the internal and finger-shaped injections seen. The overpressure estimate for finger-shaped injections plotted is for the elastic model (Eq. 2), but viscous deformation of the surrounding units would decrease the overpressure required.

16-29 MPa only occurs at depths of $\sim 2 \mathrm{~km}$ for a conduit with the same parameters as above. Conduit constriction, not considered by the Degruyter et al. (2012) model, may allow greater gas pressures to be produced at shallower depths; Castro et al. (2016) find that at $300 \mathrm{~m}$ depth, reducing conduit width from $400 \mathrm{~m}$ to only $25 \mathrm{~m}$ can increase the gas pressure by $\sim 7 \mathrm{MPa}$. However, even with conduit constriction, a total pressure of 22-35 $\mathrm{MPa}$ at $500 \mathrm{~m}$ depth is unfeasible. Additionally, such a high fluid pressure would vastly exceed the tensile strength of all country rock lithologies, and be expected to induce significant damage, which is not seen. We therefore conclude that the emplacement of the tuffisite as one single unit requires an unrealistically high gas pressure at $500 \mathrm{~m}$ depth, and is therefore untenable as a model.

The pulsed emplacement model requires a more modest $P_{W}$ compared with the single-shot model, because the pressure required for each incremental injection scales with the partial dilation width (Eq. 2). Many of the tuffisite units, particularly the coarser grained facies $(\mathrm{mlBr}$ and $\mathrm{dslBr})$ are visibly continuous across the whole length of the outcrop, and we therefore choose a model unit length of $40 \mathrm{~m}$. Some of the finer-grained tuffisite units are less laterally continuous, but this discontinuity is interpreted as occurring due to erosion, rather than representing the original depositional length of the unit. Field evidence suggests that the tuffisite was deposited in 3 main phases, separated by erosional surfaces (Figure 12). Each phase consists of multiple units of varying characteristics, and often with erosive boundaries. The three phases are therefore interpreted to reflect changes in depositional style as the tuffisite evolves, and are each formed of multiple fluid pulses. The model unit width is taken to be $10 \mathrm{~cm}$, the average width of units of facies mlBR, dslBR, mLT, and dsLT. Units of facies $\mathrm{mT}$ and sT are typically thinner than $10 \mathrm{~cm}$ and are the least laterally continuous. We suggest that the formation of many of these thinner units is driven by internal fluid pressure fluctuations within the tuffisite, rather than by fluid pressure variations of the source.

Using the range for $E$ given above ( $E=1.4$ to $E=2.4 \mathrm{GPa}$ ), injection of a $10 \mathrm{~cm}$-thick, $40 \mathrm{~m}$-long unit, consistent with the emplacement of the entire tuffisite fill in nine successive pulses, would require overpressure of $1.9 \lesssim P_{W} \lesssim 3.3 \mathrm{MPa}$ (Figure 13). Attainment of this lower $P_{W}$ value is far more plausible, and is similar to previous estimates for the overpressure forming tuffisites (Heiken et al., 1988; Saubin et al., 2016) and rhyolitic conduit systems (Benson et al., 2012; Castro et al., 2016). At 500 $\mathrm{m}$ depth the model by Degruyter et al. (2012) predicts $2-3 \mathrm{MPa}$ of gas overpressure at $500 \mathrm{~m}$ depth for a conduit width of $30 \mathrm{~m}$, consistent with our estimates and our field evidence found here.

We note that the analysis presented above could be repeated, but for a case of a non-porous overlying country rock, for which $\rho$ and $V_{p}$, and therefore $P_{L}$ and $P_{W}$, would be higher. However, we note that our estimate of $\phi=0.3$ is typical of a rhyolitic central volcano dominated by pyroclastic sequences.

The single-shot model appears to be infeasible for a thick tuffisite such as that at Húsafell, evidenced by its complex internal structure (Figures 1, 12). The dimensions of the sedimentary units suggest that the tuffisite reached a maximum overpressure of 1.9-3.3 $\mathrm{MPa}$, with fluid pressure fluctuations causing erosion and deposition, producing complex structures. The tuffisite must therefore have formed by pulsatory opening and closing, indicating an unsteady source with fluctuating fluid pressure, though some variation in fluid pressure may be generated by internal processes (see section "A Record of Fluid Pressure Fluctuations"). The overpressure required for tuffisite emplacement, 1.9-3.3 $\mathrm{MPa}$, is similar to the overpressure just above the level of fragmentation, perhaps suggesting that the formation of lateral fractures, able to host tuffisites, is inevitable just above the level of fragmentation. The overpressure estimate is also consistent with the pressure changes inferred from diffusion, with $\mathrm{H}_{2} \mathrm{O}$ concentrations in glass-walled tuffisites suggesting transient pressure drops of a few megapascals during fracture opening (Castro et al., 2014).

\section{Emplacing Finger-Shaped Injections (Structure 5)}

Field evidence suggests that the finger-shaped injections did not form by fracture opening, subsequent fluid flow and deposition of material, but instead by local distributed deformation of the material above the injection (Figures 4, 11). This is more consistent with the viscous intrusion of a granular medium, fingering into locally deformable surroundings. The fingershaped injections appear similar to structures produced by the slow intrusion of one granular medium into a second fluidsaturated granular medium, as investigated experimentally in 2D Hele Shaw cells (Saffman and Taylor, 1958; Trevelyan et al., 2011). We draw this analogy between the finger-shaped injections and experimental results in order to suggest that the finger-shaped injections represent a low velocity process that is likely to have occurred toward the end of tuffisite evolution (Phase 3 ). In turn, this would require that the pressures driving these intrusions 
were lower than expected via application of the analysis presented in section "Constraints on Tuffisite Emplacement Conditions" (Figure 13).

We note some important differences between the observations of the finger-shaped injections and the processes operative in the 2D Hele Shaw cells (Saffman and Taylor, 1958; Trevelyan et al., 2011). Most importantly, the roof material of the finger-shaped injections is locally partially sintered-a process that cannot be simulated in the low-temperature analogue experiments. This observation also points to a slow, lower-pressure, ductile process rather than the rapid, brittle repeated fracture-opening process invoked for the other units in the tuffisite. Sintering of hot pyroclasts above the finger-shaped injections would be a viscous process, and the pressure required to drive that would depend on the balance between the interstitial gas pressure and the squeezing pressure (Wadsworth et al., 2019). The upper bound on the squeezing pressure is the lithostatic pressure of 6.2 $\mathrm{MPa}$ (as discussed in section "Constraints on Tuffisite Emplacement Conditions"), but the gas pressure is unconstrained. Viscous deformation of the roof material that is associated with intrusion injection would allow space for the intrusion to be produced without requiring lithostatic pressure to be exceeded. In a particle-filled fracture the gas pressure is less than lithostatic pressure, but could still be sufficient to deform the overlying material, allowing the finger-shaped injections to form at a relative underpressure, particularly as exceeding lithostatic pressure may cause the overlying material to instead be preferentially lifted to form a fracture. In turn, this is consistent with the finger-shaped injections occurring after the high-pressure fluidised formation of the other units, and thus toward the end of tuffisite evolution, with an overall waning fluid pressure at the source (Phase 3 ).

\section{Tuffisites as a Fossil Record of Fluid Pressure Fluctuations}

The structures inside the Húsafell tuffisite provide a detailed record of the fluid pressure fluctuations during its formation. Elastically opening a space $0.1 \mathrm{~m}$ wide and $40 \mathrm{~m}$ long for each unit to be injected required 1.9-3.3 MPa of fluid overpressure, and as the fluid pressure waned particles could then be deposited. The fluid overpressure therefore appears to have oscillated, reaching a maximum of 1.9-3.3 MPa during tuffisite formation, with fluid pressure increases allowing for the erosion of previous units. Toward the end of tuffisite evolution the fluid pressure continued to wane, with finger-shaped injections formed at a lower fluid pressure than the previous sedimentary units $(<1.9-3.3 \mathrm{MPa})$.

While some smaller tuffisites do appear to have a simple structure formed by a single fluid pulse (e.g., internal tuffisites at Chaitén; Saubin et al., 2016), the complex structure of the Húsafell tuffisite suggests that it was formed by multiple pulses of material injected into the same fracture. The three phases of deposition described in the model above are the minimum number of injections that occurred during the formation of the Húsafell tuffisite-if the units of each individual phase were each formed by a fluid pulse, there could have been around as many as 20 injections of material into the fracture.

\section{Tuffisites as a Seismic Source}

Pulsed injection of pressurised fluid into a hydrofracture ( $p$ ulsed emplacement model) has been previously suggested in the context of seismic swarms at restless volcanoes (e.g., Chouet, 1996; Kumagai and Chouet, 1999). Swarms of long-period earthquakes (also called low-frequency, and here abbreviated to LP) with very similar waveforms can last for a period of a few hours to several days, with inferred trigger mechanisms involving the repeated excitation of pre-existing cracks. LP events are thought to represent a sudden pressure change within a resonated crack, and may superimpose to create sustained harmonic tremor, which has a common source process that differs only in duration (Chouet, 1996). The quality factor, Q, describes the degree of seismic attenuation, with high $Q$-values representing longlasting oscillations. To produce long-lasting oscillations with $\mathrm{Q}$ significantly greater than 100 , there needs to be a large density difference between the fluid and the surrounding rock (Chouet, 1996). Computed synthetic waveforms for fluid-filled cracks indicate that very high $Q$-values (e.g., $Q=400$ at Tungurahua Volcano, Molina et al., 2004) are best explained if the fluid is a dusty or misty gas with low sound speed (Kumagai and Chouet, 2000; Taguchi et al., 2021). In this volcanic scenario, the dust is inferred to be fine-grained particles of volcanic ash.

At Tungurahua volcano, Molina et al. (2004) modelled resonance of a fracture at $1 \mathrm{~km}$ depth, with a length:width (L/W) ratio of 2 , length:aperture ratio of $10^{4}$, and length of $\sim 200$ $\mathrm{m}$, approximately similar to the Húsafell tuffisite. Molina et al. (2004) attributed the systematically changing $Q$-value during an LP swarm to incremental filling of the fracture by $10 \mu \mathrm{m}$ ash particles, with eventual crack clogging proposed to have permitted the pressurisation that culminated in an explosive event. This particle size broadly matches that of the Húsafell tuffisite, as well as other documented tuffisite veins for which more detailed particle size analysis has been conducted (e.g., Saubin et al., 2016; Heap et al., 2019). A similar model has been proposed at Galeras volcano, with LP events suggested to represent the propagation and increase in volume of a vertical crack injected by a gas-ash mixture (Taguchi et al., 2018). Both the crack volume and mass fraction of gas within the crack were inferred to have decreased as ash was deposited and welded before the next LP event (Taguchi et al., 2021). We propose that the Húsafell tuffisite represents the fossil record of exactly this type of LP seismic swarm.

Internal tuffisites, which have previously attracted much attention as a potential source of LP earthquakes, are thought to originate in brittle failure events in magma at high strain rates (e.g., Tuffen and Dingwell, 2005; Neuberg et al., 2006). Healing and resealing of these fractures could then permit their repeated reactivation, with a minimum repeat time of a few tens of seconds (Tuffen et al., 2003). However, the modest dimensions of documented internal tuffisites ( $\leq 5 \mathrm{~m}$; Tuffen et al., 2003) fall short of the crack dimensions of tens to hundreds of metres in length that are required by crack resonance models (Chouet, 1996; Molina et al., 2004). The small interevent times between LP events are also difficult to explain using the model of magma breaking and healing, unless magma is continually 
ascending in the seismogenic window (Neuberg et al., 2006; Chouet and Matoza, 2013). We therefore propose that the much more extensive external tuffisite at Húsafell is a better candidate geological record of the LP seismic source process. External tuffisites have the potential to grow to these dimensions, as evidenced by tuffisites at Inyo Domes, California, suggested to extend $>120 \mathrm{~m}$ from a dyke (Heiken et al., 1988).

Detailed characterisation of seismicity accompanying dyke propagation in Icelandic rift zones, such as at Bárðarbunga in 2014 (Ágústsdóttir et al., 2016; Eibl et al., 2017; Woods et al., 2019), has shown that dyke propagation in the uppermost Icelandic crust $(<3 \mathrm{~km})$ is not accompanied by the high-frequency volcano-tectonic (VT) events that are normally characteristic of brittle rock failure. Magmatic pathway propagation is instead thought to involve the widening of preexisting fractures in weak material (Ágústsdóttir et al., 2016; Woods et al., 2019). Low-amplitude tremor was detected, instead of VT events, and interpreted as a swarm of micro-earthquakes at the propagating dyke tip (Eibl et al., 2017). If we apply this understanding of rift zone seismicity to the structural and lithological context of an Icelandic central volcano then we can speculate on the nature of the seismicity triggered during the opening and lifespan of the Húsafell tuffisite. As the tuffisite initially propagated by widening pre-existing fractures in the weak, overlying red ignimbrite, no high-frequency VT events would have been triggered. Instead, the seismicity would have been low-frequency and solely related to the excitation of preexisting cracks. However, fracturing of stronger neighbouring formations by the rhyolitic intrusion, such as the underlying conglomerates and black ignimbrite, and overlying basaltic lavas (McGowan, 2016; Saubin et al., 2019), may have involved bursts of seismogenic rupture and small-magnitude higher frequency events. The architecture of diverse country rock lithologies with contrasting mechanical properties therefore guides the spatial distribution and nature of seismicity on the opening and then active magmatic pathway.

\section{Repeated Injections and Deformation Style}

The strength of the surrounding tuffisite units must control the location of finger-shaped injections. In a theoretical homogenous tuffisite emplaced in a single pulse, the material closest to the colder country rock should cool most rapidly, and therefore will be less well sintered, weaker, and easier to inject (Kolzenburg et al., 2019). However, in the heterogeneous Húsafell tuffisite, involving emplacement over multiple pulses, the cooling history is more complex. To form a finger-shaped injection the overlying unit requires sufficient cohesion to form a roof, but must maintain the ability to viscously deform at the time of injection, and thus be at high temperature, perhaps aided by additional heat from the injected material. In the Húsafell tuffisite the position of finger-shaped injections will reflect the relative ages and temperatures of material deposited by different fluid pulses. The finger-shaped injections are seen around the centre of the tuffisite width, where slow cooling would allow for the greatest degree of sintering (Kolzenburg et al., 2019), decreasing permeability and allowing fluid pressure to build, and favouring viscous deformation of the tuffisitic roof material. Fluid is injected along the contact between a slow cooled and well-sintered strong unit below, and a younger unit above, deposited by a later fluid pulse, which was still sufficiently hot to viscously deform.

The tuffisite therefore appears to be self-limiting in its lifetime as a degassing pathway. A less-evolved tuffisite with fewer fluid pulses will be colder, allowing material to be more easily injected, and will remain more permeable, allowing for greater amounts of fluid flow. As more pulses are injected and the tuffisite thickens it will take longer to cool, allowing for more sintering to take place, reducing tuffisite permeability. Waning fluid pressure in a hot tuffisite favours the formation of fingershaped injections, viscously deforming the overlying layers and reducing permeability further.

\section{Future Challenges}

Tuffisites are a fossil record of the processes occurring during the formation and evolution of magmatic pathways. Quantifying the fluid pressure required to open these fractures, by characterising the mechanical properties of tuffisite host rocks, would inform new models of magma ascent dynamics during pre-eruptive unrest. The field evidence presented here suggests that single-shot models of tuffisite emplacement and associated cooling models are not appropriate, and that a full model for tuffisite emplacement is needed in which fracture width and sedimentation and erosion are coupled in a full dynamic model. Only then could the outgassing flux of tuffisites be properly computed to help assess whether tuffisites can act as pressure release valves capable of modulating the style of silicic eruptions. Finally, swarms of shallow volcanic earthquakes are thought to relate to fluid injection into particle-choked fracture pathways (e.g., Molina et al., 2004). Informing seismic source modelling by using constraints from the tuffisite fossil record could yield improved understanding of the nature of volcanic unrest and its relationship with subsurface magma movement.

\section{CONCLUSION}

Our characterisation of a particle-filled hydrofracture provides insights into tuffisite formation processes. Complex structures indicate that the tuffisite was formed by multiple fluid pulses, controlled by fluctuations in the fluid pressure, and variations in the fill characteristics record changes in the fluid-particle concentration of the injected fluid. The dimensions of each sedimentary unit ( $40 \mathrm{~m}$ long and $0.1 \mathrm{~m}$ thick) can be used to estimate that an overpressure of $\sim 1.9-3.3 \mathrm{MPa}$ was required for their formation, assuming only elastic deformation of the surrounding material, giving a total required pressure of $\sim 9 \mathrm{MPa}$ at $500 \mathrm{~m}$ depth including lithostatic pressure. The overpressure, as recorded by sedimentary structures in the tuffisite, appears to have reached a maximum of $\sim 1.9-3.3 \mathrm{MPa}$, similar to the expected gas pressure just above the region of magma fragmentation within the main conduit, before waning at the end of tuffisite evolution. Viscous deformation can be seen around some injections, suggesting that if a tuffisite can become 
thick enough to sufficiently insulate material toward the end of its lifetime, injections can occur at a lower fluid pressure, deforming the surrounding material and causing permeability to rapidly decrease. The Húsafell tuffisite has similar dimensions to fractures filling with ash that have been modelled as the source of LP seismic swarms, providing a fossil record of otherwise unobservable processes that are a key component of volcanic unrest.

\section{DATA AVAILABILITY STATEMENT}

The original contributions presented in the study are included in the article/supplementary material, further inquiries can be directed to the corresponding author/s.

\section{AUTHOR CONTRIBUTIONS}

HU, HT, and FW conducted fieldwork at Húsafell. HU analysed samples with assistance from EP and HT, and devised the formation model with assistance from HT, FW, and MJ. All authors contributed to the project design and preparation of the manuscript.

\section{REFERENCES}

Ágústsdóttir, T., Woods, J., Greenfield, T., Green, R. G., White, R. S., Winder, T., et al. (2016). Strike-slip faulting during the 2014 Bárðarbunga-Holuhraun dike intrusion, central Iceland. Geophys. Res. Lett. 43, 1495-1503. doi: 10.1002/ 2015GL067423

Ágústsdóttir, T., Gudmundsson, M., and Einarsson, P. (2011). A gravity study of silicic domes in the Krafla area, N-Iceland. Jokull 60, 135-148.

Al-Harthi, A. A., Al-Amri, R. M., and Shehata, W. M. (1999). The porosity and engineering properties of vesicular basalt in Saudi Arabia. Eng. Geol. 54, 313-320. doi: 10.1016/S0013-7952(99)00050-2

Allen, J. R. L. (1982). Sedimentary Structures: Their Character and Physical Basis, Vol. 2. Amsterdam: Elsevier. doi: 10.1016/0025-3227(83)90103-2

Benson, P. M., Heap, M. J., Lavallée, Y., Flaws, A., Hess, K.-U., Selvadurai, A. P. S., et al. (2012). Laboratory simulations of tensile fracture development in a volcanic conduit via cyclic magma pressurisation. Earth Planet. Sci. Lett. 349-350, 231-239. doi: 10.1016/J.EPSL.2012.07.003

Berlo, K., Tuffen, H., Smith, V., Castro, J. M., Pyle, D. M., Mather, T. A., et al. (2013). Element variations in rhyolitic magma resulting from gas transport. Geochim. Cosmochim. Acta 121, 436-451. doi: 10.1016/J.GCA.2013. 07.032

Boehm, A., and Moore, J. C. (2002). Fluidized sandstone intrusions as an indicator of Paleostress orientation, Santa Cruz, California. Geofluids 2, 147-161. doi: 10.1046/j.1468-8123.2002.00026.x

Branney, M. J., and Kokelaar, P. (2002). Chapter 4: conceptualizing deposition: a flow-boundary zone approach. Pyrocl. Den. Currr. Sediment. Ignimbr. 27, 37-49. doi: 10.1144/GSL.MEM.2003.027.01.04

Castro, J. M., Bindeman, I., Tuffen, H., and Schipper, C. I. (2014). Explosive origin of silicic lava: textural and $-\mathrm{H} 2 \mathrm{O}$ evidence for pyroclastic degassing during rhyolite effusion. Earth Planet. Sci. Lett. 405, 52-61.

Castro, J. M., Cordonnier, B., Schipper, C. I., Tuffen, H., Baumann, T. S., and Feisel, Y. (2016). Rapid laccolith intrusion driven by explosive volcanic eruption. Nat. Commun. 7:13585. doi: 10.1038/ncomms 13585

Castro, J. M., Cordonnier, B., Tuffen, H., Tobin, M. J., Puskar, L., Martin, M. C., et al. (2012). The role of melt-fracture degassing in defusing explosive rhyolite eruptions at volcán Chaitén. Earth Planet. Sci. Lett. 333-334, 63-69. doi: 10. 1016/J.EPSL.2012.04.024

\section{FUNDING}

HU was supported by the NERC Envision studentship and a BUFI grant from the British Geological Survey. EP publishes with the permission of the Executive Director of the British Geological Survey. HT was supported by the Royal Society University Research Fellowship UF140716 and Royal Society International Exchanges grant IE150771.

\section{ACKNOWLEDGMENTS}

We thank Adrian White for his assistance with fieldwork at Húsafell in the summer of 2019 and Kristján Sæmundsson for sharing his knowledge of the Húsafell central volcano. We are grateful to the landowners for granting access to the field site and Náttúrufræðistofnunar Íslands for sampling permission. The study benefited from helpful discussions with Dave McGarvie, Michael Heap, Alexandra Kushnir, Lucille Carbillet, Steffi Burchardt, Tobias Schmiedel, Emma Rhodes, and Taylor Witcher. We acknowledge major contributions to our understanding of Húsafell from earlier studies by Ellen McGowan and Elodie Saubin. We are grateful to the two reviewers and the editor for their constructive and insightful comments that have improved the manuscript.

Chouet, B. A. (1996). Long-period volcano seismicity: its source and use in eruption forecasting. Nature 380, 309-316. doi: 10.1038/380309a0

Chouet, B. A., and Matoza, R. S. (2013). A multi-decadal view of seismic methods for detecting precursors of magma movement and eruption. J. Volcanol. Geoth. Res. 252, 108-175. doi: 10.1016/J.JVOLGEORES.2012.11.013

Cobain, S. L., Peakall, J., and Hodgson, D. M. (2015). Indicators of Propagation Direction and Relative Depth in Clastic Injectites: Implications for Laminar Versus Turbulent Flow Processes. Boulder, CO: Geological Society of America. doi: 10.1130/B31209.1

Colombier, M., Burgisser, A., Cáceres, F., Druitt, T., Gurioli, L., Hess, K.-U., et al. (2020). Rheological change and degassing during a trachytic vulcanian eruption at kilian volcano, chaîne des puys, france. Bull. Volcanol. 82, 463-463. doi: $10.46427 /$ gold 2020.463

Cosgrove, J. W. (2001). Hydraulic fracturing during the formation and deformation of a basin: A factor in the dewatering of low-permeability sediments. AAPG Bull. 85, 737-748.

Degruyter, W., Bachmann, O., Burgisser, A., and Manga, M. (2012). The effects of outgassing on the transition between effusive and explosive silicic eruptions. Earth Planet. Sci. Lett. 349-350, 161-170. doi: 10.1016/j.epsl.2012.06.056

Dewan, J. T., and Chenevert, M. E. (2001). A model for filtration of water-base mud during drilling: Determination of mudcake parameters. Petrophysics 42, 237-250.

Duranti, D., and Hurst, A. (2004). Fluidization and injection in the deep-water sandstones of the Eocene Alba Formation (UK North Sea). Sedimentology 51, 503-529. doi: 10.1111/j.1365-3091.2004.00634.x

Eibl, E. P. S., Bean, C. J., Vogfjörd, K. S., Ying, Y., Lokmer, I., Möllhoff, M., et al. (2017). Tremor-rich shallow dyke formation followed by silent magma flow at Bárarbunga in Iceland. Nat. Geosci. 10, 299-304. doi: 10.1038/ngeo2906

Eichelberger, J. C., Carrigan, C. R., Westrich, H. R., and Price, R. H. (1986). Non-explosive silicic volcanism. Nature 323, 598-602. doi: 10.1038/ $323598 \mathrm{a} 0$

Farquharson, J. I., Wadsworth, F. B., Heap, M. J., and Baud, P. (2017). Timedependent permeability evolution in compacting volcanic fracture systems and implications for gas overpressure. J. Volcanol. Geoth. Res. 339, 81-97. doi: 10.1016/J.JVOLGEORES.2017.04.025

Farquharson, J., Heap, M. J., Varley, N. R., Baud, P., and Reuschlé, T. (2015). Permeability and porosity relationships of edifice-forming andesites: 
a combined field and laboratory study. J. Volcanol. Geoth. Res. 297, 52-68. doi: 10.1016/j.jvolgeores.2015.03.016

Ferguson, C., and Klotz, J. A. (1954). Filtration from mud during drilling. J. Petrol. Technol. 6, 30-43. doi: 10.2118/289-g

Fisher, R. V., Schmincke, H. U., and Van Bogaard, P. (1983). Origin and emplacement of a pyroclastic flow and surge unit at Laacher See, Germany. J. Volcanol. Geoth. Res. 17, 375-392. doi: 10.1016/0377-0273(83)90077-X

Gardner, J. E., Wadsworth, F. B., Llewellin, E. W., Watkins, J. M., and Coumans, J. P. (2018). Experimental sintering of ash at conduit conditions and implications for the longevity of tuffisites. Bull. Volcanol. 80:23. doi: 10.1007/ s00445-018-1202-8

Geshi, N., Kusumoto, S., and Gudmundsson, A. (2012). Effects of mechanical layering of host rocks on dike growth and arrest. J. Volcanol. Geoth. Res. 223-224, 74-82. doi: 10.1016/J.JVOLGEORES.2012.02.004

Gudmundsson, A. (1983). Stress estimates from the length/width ratios of fractures. J. Struct. Geol. 5, 623-626. doi: 10.1016/0191-8141(83)90075-5

Gudmundsson, A. (2011). Deflection of dykes into sills at discontinuities and magma-chamber formation. Tectonophysics 500, 50-64. doi: 10.1016/J.TECTO. 2009.10.015

Heap, M. J., Tuffen, H., Wadsworth, F. B., Reuschlé, T., Castro, J. M., and Schipper, C. I. (2019). The permeability evolution of tuffisites and implications for outgassing through dense rhyolitic magma. J. Geophys. Res. Solid Earth 124, 8281-8299. doi: 10.1029/2018JB017035

Heap, M. J., Villeneuve, M., Albino, F., Farquharson, J. I., Brothelande, E., Amelung, F., et al. (2020). Towards more realistic values of elastic moduli for volcano modelling. J. Volcanol. Geoth. Res. 390:106684. doi: 10.1016/j. jvolgeores.2019.106684

Heiken, G., Wohletz, K., and Eichelberger, J. (1988). Fracture fillings and intrusive pyroclasts, Inyo Domes, California. J. Geophys. Res. Solid Earth 93, 4335-4350. doi: 10.1029/JB093iB05p04335

Hubbert, M. K., and Willis, D. G. (1957). Mechanics of hydraulic fracturing. Transact. AIME 210, 153-168.

Hurst, A., Scott, A., and Vigorito, M. (2011). Physical characteristics of sand injectites. Earth Sci. Rev. 106, 215-246. doi: 10.1016/J.EARSCIREV.2011.02.004

Isgett, S. J., Houghton, B. F., Fagents, S. A., Biass, S., Burgisser, A., and Arbaret, L. (2017). Eruptive and shallow conduit dynamics during Vulcanian explosions: insights from the Episode IV block field of the 1912 eruption of Novarupta, Alaska. Bull. Volcanol. 79:1138. doi: 10.1007/s00445-017-1138-4

Jaupart, C. (1998). Gas loss from magmas through conduit walls during eruption. Geol. Soc. Spec. Public. 145, 73-90. doi: 10.1144/GSL.SP.1996.145.01.05

Jolly, R. J. H., and Lonergan, L. (2002). Mechanisms and controls on the formation of sand intrusions. J. Geol. Soc. 159, 605-617. doi: 10.1144/0016-764902-025

Jonk, R. (2010). Sand-rich injectites in the context of short-lived and long-lived fluid flow. Basin Res. 22, 603-621. doi: 10.1111/j.1365-2117.2010.00471.x

Kendrick, J. E., Lavallée, Y., Varley, N. R., Wadsworth, F. B., Lamb, O. D., and Vasseur, J. (2016). Blowing off steam: tuffisite formation as a regulator for lava dome eruptions. Front. Earth Sci. 4:41. doi: 10.3389/feart.2016.00041

Kern, L. R., Perkins, T. K., and Wyant, R. E. (1959). The mechanics of sand movement in fracturing. J. Petrol. Technol. 11, 55-57. doi: 10.2118/1108-G

Kolzenburg, S., Ryan, A. G., and Russell, J. K. (2019). Permeability evolution during non-isothermal compaction in volcanic conduits and tuffisite veins: implications for pressure monitoring of volcanic edifices. Earth Planet. Sci. Lett. 527:115783. doi: 10.1016/j.epsl.2019.115783

Kumagai, H., and Chouet, B. A. (1999). The complex frequencies of long-period seismic events as probes of fluid composition beneath volcanoes. Geophys. J. Int. 138, F7-F12. doi: 10.1046/j.1365-246X.1999.00911.x

Kumagai, H., and Chouet, B. A. (2000). Acoustic properties of a crack containing magmatic or hydrothermal fluids. J. Geophys. Res. Solid Earth 105, 2549325512. doi: 10.1029/2000JB900273

Lavallée, Y., Benson, P. M., Heap, M. J., Hess, K.-U., Flaws, A., Schillinger, B., et al. (2013). Reconstructing magma failure and the degassing network of dome-building eruptions. Geology 41, 515-518. doi: 10.1130/G33948.1

McGowan, E. (2016). Magma Emplacement and Deformation in Rhyolitic Dykes: Insight Into Magmatic Outgassing. Doctoral dissertation. Lancaster: Lancaster University.

Molina, I., Kumagai, H., and Yepes, H. (2004). Resonances of a volcanic conduit triggered by repetitive injections of an ash-laden gas. Geophys. Res. Lett. 31:L03603. doi: 10.1029/2003GL018934
Neuberg, J. W., Tuffen, H., Collier, L., Green, D., Powell, T., and Dingwell, D. (2006). The trigger mechanism of low-frequency earthquakes on Montserrat. J. Volcanol. Geoth. Res. 153, 37-50. doi: 10.1016/J.JVOLGEORES.2005. 08.008

Okumura, S., and Sasaki, O. (2014). Permeability reduction of fractured rhyolite in volcanic conduits and its control on eruption cyclicity. Geology 42, 843-846. doi: $10.1130 / \mathrm{G} 35855.1$

Owen, J., Tuffen, H., and McGarvie, D. W. (2013). Explosive subglacial rhyolitic eruptions in Iceland are fuelled by high magmatic $\mathrm{H}_{2} \mathrm{O}$ and closed-system degassing. Geology 41, 251-254. doi: 10.1130/G33647.1

Özsan, A., and Akn, M. (2002). Engineering geological assessment of the proposed Uruş Dam, Turkey. Eng. Geol. 66, 271-281. doi: 10.1016/S0013-7952(02)00 047-9

Paisley, R., Berlo, K., Ghaleb, B., and Tuffen, H. (2019a). Geochemical constraints on the role of tuffisite veins in degassing at the 2008-09 Chaitén and 201112 Cordón Caulle rhyolite eruptions. J. Volcanol. Geoth. Res. 380, 80-93. doi: 10.1016/j.jvolgeores.2019.05.013

Paisley, R., Berlo, K., Whattam, J., Schipper, C. I., and Tuffen, H. (2019b). Degassing-induced chemical heterogeneity at the 2011-2012 Cordón Caulle eruption. Volcanica 2, 211-237. doi: 10.30909/vol.02.02.211237

Perkins, T. K., and Kern, L. R. (1961). Widths of hydraulic fractures. J. Petrol. Technol. 13, 937-949. doi: 10.2118/89-PA

Phillips, E., and Hughes, L. (2014). Hydrofracturing in response to the development of an overpressurised subglacial meltwater system during drumlin formation: an example from Anglesey, NW Wales. Proc. Geol. Associat. 125, 296-311. doi: 10.1016/J.PGEOLA.2014.03.004

Phillips, E., and Kearsey, T. I. (2020). Mass flow and hydrofracturing during Late Devensian moraine emplacement, NE Scotland. Proc. Geol. Associat. 131, 730-750. doi: 10.1016/j.pgeola.2020.08.002

Phillips, E., Everest, J., and Reeves, H. (2013). Micromorphological evidence for subglacial multiphase sedimentation and deformation during overpressurized fluid flow associated with hydrofracturing. Boreas 42, 395-427. doi: 10.1111/j. 1502-3885.2012.00261.x

Ravier, E., Buoncristiani, J.-F., Guiraud, M., Menzies, J., Clerc, S., Goupy, B., et al. (2014). Porewater pressure control on subglacial soft sediment remobilization and tunnel valley formation: a case study from the Alnif tunnel valley (Morocco). Sediment. Geol. 304, 71-95. doi: 10.1016/J.SEDGEO.2014. 02.005

Rijsdijk, K. F., Owen, G., Warren, W. P., McCarroll, D., and van der Meer, J. J. (1999). Clastic dykes in over-consolidated tills: evidence for subglacial hydrofracturing at Killiney Bay, eastern Ireland. Sediment. Geol. 129, 111-126. doi: 10.1016/S0037-0738(99)00093-7

Rivalta, E., Taisne, B., Bunger, A. P., and Katz, R. F. (2015). A review of mechanical models of dike propagation: schools of thought, results and future directions. Tectonophysics 638, 1-42.

Rubin, A. M. (1995). PROPAGATION OF MAGMA-FILLED CRACKS. Annu. Rev. Earth Planet. Sci. 23, 287-336.

Rust, A. C., Cashman, K. V., and Wallace, P. J. (2004). Magma degassing buffered by vapor flow through brecciated conduit margins. Geology 32, 349. doi: 10. $1130 / \mathrm{G} 20388.2$

Sæmundsson, K., and Noll, H. (1974). K-Ar ages of rocks from Husafell, western Iceland, and the Development of the Husafell Central Volcano. Jökull 24, 40-59.

Saffman, P. G., and Taylor, G. I. (1958). The penetration of a fluid into a porous medium or Hele-Shaw cell containing a more viscous liquid. Proc. R. Soc. Lond. Ser. A Math. Phys. Sci. 245, 312-329. doi: 10.1098/rspa.1958.0085

Saubin, E., Kennedy, B., Tuffen, H., Villeneuve, M., Davidson, J., and Burchardt, S. (2019). Comparative field study of shallow rhyolite intrusions in Iceland: emplacement mechanisms and impact on country rocks. J. Volcanol. Geoth. Res. 388:106691. doi: 10.1016/j.jvolgeores.2019.106691

Saubin, E., Tuffen, H., Gurioli, L., Owen, J., Castro, J. M., Berlo, K., et al. (2016). Conduit dynamics in transitional rhyolitic activity recorded by tuffisite vein textures from the 2008-2009 Chaitén Eruption. Front. Earth Sci. 4:59. doi: $10.3389 /$ feart.2016.00059

Scott, A., Vigorito, M., and Hurst, A. (2009). The process of sand injection: internal structures and relationships with host strata (Yellowbank Creek Injectite Complex, California, U.S.A.). J. Sediment. Res. 79, 568-583. doi: 10.2110/jsr. 2009.062 
Sparks, R. S. J. (1976). Grain size variations in ignimbrites and implications for the transport of pyroclastic flows. Sedimentology 23, 147-188. doi: 10.1111/j.13653091.1976.tb00045.x

Stasiuk, M. V., Barclay, J., Carroll, M. R., Jaupart, C., Ratté, J. C., Sparks, R. S. J., et al. (1996). Degassing during magma ascent in the Mule Creek vent (USA). Bull. Volcanol. 58, 117-130. doi: 10.1007/s004450050130

Taguchi, K., Kumagai, H., Maeda, Y., and Torres, R. (2018). Source properties and triggering processes of long-period events beneath volcanoes inferred from an analytical formula for crack resonance frequencies. Wiley Online Lib. 123, 7550-7565. doi: 10.1029/2018JB015866

Taguchi, K., Kumagai, H., Maeda, Y., and Torres, R. (2021). Empirical formula for the quality factors of crack resonances and its application to the estimation of source properties of long-period seismic events at active volcanoes. Geophys. J. Int. 224, 2131-2148. doi: 10.1093/gji/ggaa519

Taisne, B., and Jaupart, C. (2009). Dike propagation through layered rocks. J. Geophys. Res. Solid Earth 114.

Trevelyan, P. M. J., Almarcha, C., and De Wit, A. (2011). Buoyancy-driven instabilities of miscible two-layer stratifications in porous media and Hele-Shaw cells. J. Fluid Mech. 670, 38-65. doi: 10.1017/S0022112010005008

Tuffen, H., and Dingwell, D. (2005). Fault textures in volcanic conduits: Evidence for seismic trigger mechanisms during silicic eruptions. Bull. Volcanol. 67, 370-387. doi: 10.1007/s00445-004-0383-5

Tuffen, H., Dingwell, D. B., and Pinkerton, H. (2003). Repeated fracture and healing of silicic magma generate flow banding and earthquakes? Geology 31, 1089. doi: 10.1130/G19777.1

Van Der Meer, J. J. M., Kjaer, K. H., and Krüger, J. (1999). Subglacial water-escape structures and till structures, Slettjokull, Iceland. J. Q. Sci. 14, 191-205. doi: 10.1002/(sici)1099-1417(199905)14:3<191::aid-jqs436<3.0.co;2-\#

van der Meer, J. J. M., Kjær, K. H., Krüger, J., Rabassa, J., and Kilfeather, A. A. (2009). Under pressure: clastic dykes in glacial settings. Q. Sci. Rev. 28, 708-720. doi: 10.1016/j.quascirev.2008.07.017

Vasseur, J., Wadsworth, F. B., Lavallée, Y., and Dingwell, D. B. (2016). Dynamic elastic moduli during isotropic densification of initially granular media. Geophys. J. Int. 204, 1721-1728. doi: 10.1093/gji/ggv550
Wadsworth, F. B., Llewellin, E. W., Vasseur, J., Gardner, J. E., and Tuffen, H. (2020). Explosive-effusive volcanic eruption transitions caused by sintering. Sci. $A d v$. 6:7940. doi: 10.1126/sciadv.aba7940

Wadsworth, F. B., Vasseur, J., Llewellin, E. W., Brown, R. J., Tuffen, H., Gardner, J. E., et al. (2021). A model for permeability evolution during volcanic welding. J. Volcanol. Geoth. Res. 2020:107118. doi: 10.1016/j.jvolgeores.2020.107118

Wadsworth, F. B., Vasseur, J., Schauroth, J., Llewellin, E. W., Dobson, K. J., Havard, T., et al. (2019). A general model for welding of ash particles in volcanic systems validated using in situ X-ray tomography. Earth Planet. Sci. Lett. 525:115726. doi: 10.1016/j.epsl.2019.115726

Wadsworth, F. B., Vasseur, J., Scheu, B., Kendrick, J. E., Lavallée, Y., and Dingwell, D. B. (2016). Universal scaling of fluid permeability during volcanic welding and sediment diagenesis. Geology 44, 219-222. doi: 10.1130/G37559.1

Wadsworth, F. B., Vasseur, J., von Aulock, F. W., Hess, K.-U., Scheu, B., Lavallée, Y., et al. (2014). Nonisothermal viscous sintering of volcanic ash. J. Geophys. Res. Solid Earth 119, 8792-8804. doi: 10.1002/2014JB011453

Walker, G. P. L. (1984). Characteristics of dune-bedded pyroclastic surge bedsets. J. Volcanol. Geoth. Res. 20, 281-296. doi: 10.1016/0377-0273(84)90044-1

Woods, J., Winder, T., White, R. S., and Brandsdóttir, B. (2019). Evolution of a lateral dike intrusion revealed by relatively-relocated dike-induced earthquakes: the 2014-15 Bárðarbunga-Holuhraun rifting event, Iceland. Earth Planet. Sci. Lett. 506, 53-63. doi: 10.1016/j.epsl.2018.10.032

Conflict of Interest: The authors declare that the research was conducted in the absence of any commercial or financial relationships that could be construed as a potential conflict of interest.

Copyright (c) 2021 Unwin, Tuffen, Phillips, Wadsworth and James. This is an openaccess article distributed under the terms of the Creative Commons Attribution License (CC BY). The use, distribution or reproduction in other forums is permitted, provided the original author(s) and the copyright owner(s) are credited and that the original publication in this journal is cited, in accordance with accepted academic practice. No use, distribution or reproduction is permitted which does not comply with these terms. 